Western University

Scholarship@Western

Business Publications

Business (Richard Ivey School of Business)

2017

\title{
The Passion of Luc Boltanski: The destiny of love, violence and institution
}

\author{
Roger Friedland
}

Diane-Laure Arjaliès

Ivey Business School, darjalies@ivey.ca

Follow this and additional works at: https://ir.lib.uwo.ca/iveypub

Part of the Business Commons, and the Sociology Commons

Citation of this paper:

Friedland, Roger and Arjaliès, Diane-Laure, "The Passion of Luc Boltanski: The destiny of love, violence and institution" (2017).

Business Publications. 9.

https://ir.lib.uwo.ca/iveypub/9 


\title{
The Passion of Luc Boltanski: The destiny of love, violence and institution
}

\author{
Roger Friedland
}

Diane-Laure Arjaliès

Friedland R., Arjaliès D-L., (2017) The Passion of Luc Boltanski: The Destiny of Love, Violence and Institution, Research in the Sociology of Organizations, 52: 301-347

\begin{abstract}
On Justification: Economies of Worth (Boltanski and Thévenot, 1991/2006) was a synthetic and comprehensive parsing of common goods, goods that could and had to be justified in public. In response to Bourdieu's critical sociology, they rather provided a robust and disciplined sociology of critique, the situated requirements of justification. They refused power and violence as integral to the operability of justification. They emphasized the ways in which conventions of worth afforded coordination, not their constitution of or by domination. They refused to make either capitalism, or the state, into primary motors of social order. Indeed, they refused social sphere, structure or group as the ground of the good. They emphasized the cognitive capacities of agents. There was no passion, no desire, no bodily affect in these justified worlds. There wasn't even any account of production of value, of children or money. And while they recognized the metaphysical aspect of the good and even used Christianity as a template for one of their cités, they rigorously excluded religion. The theory was designed to analyze moments of controversy, not quiescence or quietude. In his subsequent work, Boltanksi aimed to address these absences. In this essay, we examine how Boltanksi sought to restore love, violence, religion, production and institution across five texts: Love and Justice as Competences (1990/2012), The New Spirit of Capitalism, co-authored with Eve Chiapello (1999/2007), The Foetal Condition: A Sociology of Engendering and Abortion (2004/2013), On Critique: A Sociology of Emancipation (2009/2011) and La "Collection», Une Forme Neuve du Capitalisme - La Mise en Valeur Economique du Passé et ses Effets (2014) co-authored with Arnaud Esquerre.
\end{abstract}

Keywords: Boltanski - Institution - Love - Orders of Worth - Power - Violence 


\section{INTRODUCTION}

Luc Boltanski now seeks to give us the truth of institution. With the publication of $O n$ Justification: Economies of Worth (1991/2006) (hereafter OJ) it was clear to all that Luc Boltanski and Laurent Thévenot had crafted a startlingly innovative theory of the conduct of justification grounded in common goods and the conventions by which these goods are evaluated (Boltanski \& Thévenot, 2006). Focusing on moments of controversy in concrete situations, they analyzed the ways in which conventions of worth are deployed in practical tests both to evaluate and to critique worth attributed to persons or things based on these metaphysical goods. Repudiating Pierre Bourdieu's generalized economics of commensurable domination, they displaced a critical sociology with a sociology of critique grounded in a generalized politics of incommensurable common goods.

It was a synthetic and comprehensive parsing of common goods, of goods that could and had to be justified in public. It located the ground of these good on the one hand, in a metaphysical and logical space clarified by political philosophers, and on the other, in ordinary justifications and their associated conventions that qualified persons and objects in terms of these goods gleaned from French management manuals. While they conceptualized these as political grammars, or "legitimate forms of agreement," their empirical warrant was primarily discursive, words systematized in political philosophy or deployed in normative texts or controversies: They studied justifications and critiques, an analytic account of accounts (Boltanski and Thévenot, 2006: 39). Although objects played a critical role in grounding the actionability and justifiability of the good (Boltanksi and Thévenot, 2006: 16), observation of the behavioral regularities of 
material practices themselves was not the empirical warrant for the theory (Boltanski, 2012: 37). It largely centered, not unlike American pluralist political scientists long ago, on what people said and agreed to do under conditions of controversy over relative worth. Nor was it a theory of society, either as a structure of class positions, a distribution of capitals, or an institutional configuration or social formation. It did not offer the classic objectivist ground for critique. In response to Bourdieu's critical sociology, they rather provided a robust and disciplined sociology of critique, the situated requirements of justification. In Boltanski's words, theirs was a model for the ways in which individuals act in "situations subjected to an imperative of justification," that is, situations subject to critique based on specific forms of injustice (Boltanski, 2012: 38).

$O J$ was an epochal work, a paradigm for an expansionary understanding of the public sphere as a multiplicitous world of common goods, of alternative ways of "establishing generality" (Boltanski, 2012: 12), neither limited by the validity claims of Habermasian communicative rationality in the life-world nor the dominant ideology of what Marxists termed civil society. Common goods cross conventional institutional boundaries, encompassing not only market worth, but fame, inspiration, industrial efficacy, civic worth, and the generative chains of domesticity. To build their beautiful political machine Boltanski and Thévenot had made a number of critical investments (Thévenot, 1984). But there were sacrifices to be made, things that had to be given up or excluded.

The first exclusion was the absence of love in their worlds of worth, love whose actuality Bourdieu had treated as a sociological miracle, a "miraculous truce," normally a mask for social determination and an eroticization of masculine domination (Bourdieu, 
2001, p. 112). There was no passion, no desire, no bodily affect in their justified worlds. Boltanski and Thévenot likewise relegated love to the shadows because of its wordlessness, and hence worldlessness, and its failure, as an intimate and idiosyncratic phenomena, to count as a common good.

The second sacrifice was the refusal of power and violence as integral to the origins and operability of justification. They emphasized the ways in which conventions of worth afforded the possibility of beneficent coordination, not their constitution of or by power and violence. Power and violence were understood as "relativizations," reductions of the justness afforded by common goods to relations of power, a position they doubly associated with Pierre Bourdieu, their one-time mentor, who ran his own atelier with a domineering, even totalitarian, hand. In their respective and conjoint deviations from their master, they had lived the dangerous life of morally engaged critique, both forced to move into intellectual and organizational exile in order to pursue their respective ways (Thévenot, 2014). ${ }^{1}$ Difference required schism.

Religion was the third sacrifice. While they recognized the metaphysical aspect of the good and even used Christianity as a template for one of its cités, that of inspiration, they rigorously excluded religion. Religion violated the terms of a republican polity with its non-contingent, and even irremediable, qualifications of human destiny and the possibility of exclusion from membership in a common humanity they entailed. ${ }^{2}$ Fourth, was their emphasis on evaluation, on the reality test as a convention for qualification of worth, displacing the theoretical rubric of production, including the production of the good itself. 
With the primacy they gave to the situation, the last sacrifice was the institution, and the groups whose domination they sustained, as structuring units of the social world. "The forms of generality and worth whose economy we describe here," they insisted, "are in fact not attached to collectivities but to situations..." (Boltanski and Thévenot, 2006: 16). They rather centered their work on the conditions for agreement under conditions of situated critique, echoing their friend and sometime fellow traveler, Bruno Latour, whose actor network theory centered on the moment and site of instituting under conditions of controversy (Latour, 2005). Their program was likewise designed for moments of potential social dis-assemblage, in particular situations evidenced by critique and justification.

In a series of texts largely composed in the aftermath of On Justification in 1991, Boltanski sought to correct some of these omissions, to recuperate domination and violence, to insert love into social life, to grapple with the logic of capitalism, and to rebuild links to critical social theory. ${ }^{1}$ To do so, he turned not to a general theory of capitals, but of institution. And he turned explicitly to religion in order to conceptualize it. In French republican political culture, invoking religion, let alone God, as a template, is saturated with taboos, unspoken fears which just now are again being shouted from every portal.

In what follows we will examine the overall architecture of Boltanski's subsequent oeuvre, by considering how Boltanksi aimed to recuperate love, power, violence, religion, production and institution in five texts: Love and Justice as

\footnotetext{
${ }^{1}$ The text that became De la justification, published in 1991, was first published in 1987 as Les économies de la grandeur, Cahiers du CEE, PUF. See Lemieux, 2014: 153. We are also grateful to Jean-Pascal Gond for clarifying the literary sequence.
} 
Competences (1990/2012), The New Spirit of Capitalism, co-authored with Eve Chiapello (1999/2007), The Foetal Condition: A Sociology of Engendering and Abortion (2004/2013), On Critique: A Sociology of Emancipation (2009/2011) and La «Collection», Une Forme Neuve du Capitalisme - La Mise en Valeur Economique du Passé et ses Effets (2014) co-authored with Arnaud Esquerre.

We shall argue that Boltanski has crafted a secularized Christian understanding of both love and institution. It is a very particular understanding, one that positions love as a dyadic miracle outside the social order, on the one side, and institution as a ritual enactment of a myth, an ideal, a heavenly idea, backed by coercion if belief falters, on the other. Without a more ample understanding of love, an account of the production of value, we cannot adequately grasp the conditions of justice, and without a more practical understanding of institution, we will fail to see how mysterious, as opposed to mystifying, the operations of institution actually are. We tell a story of the return of the repressed. It is not meant as an un-masking of Boltanski's use of categories that are religious in origin. Quite the contrary: It is meant as a provocation to a more general religious institutionalism.

\section{THE RETURN OF LOVE AND VIOLENCE}

OJ's Mode of Action: Competence and Conventions as Mutual Constituents of Justice

It is important to briefly recapitulate the orders of worth perspective. As opposed to Bourdieu's unconscious habitus or disposition inscribed in agents who classify as they are classed and who want attainable goods for themselves, Boltanski and Thévenot's actors are endowed with a "competence" for justice based on common goods, equipped 
with a capacity both to challenge and to justify worthiness (Boltanski and Thévenot, 2006). Critique is built into the human condition. Theirs is an Aristotelian understanding of justice whose "adequate measure" is "just proportion" between "the quantity of things distributed and the various qualities of persons" (Boltanski, 2012: 112-113).

Orders of worth are trinitarian conjunctions of a metaphysical good, a common good of benefit to all beyond any "self-centered pleasure" or private interest an individual may obtain from it, actors' moral competences to justify and critique based upon the principle of equivalence this good provides, and material conventions in formatted situations by which a being's goodness is subject to test as to its relative worth. For such tests to be justifiable, the principle of equivalence that a common good provides must be paired with "sets of objects" --- that together constitute a "coherent and self-sufficient world," a "natural situation" (Boltanski and Thévenot, 2006: 40-41, 19). ${ }^{3}$ In practice, justice is a "justifiable ranking of persons and things," justification a legitimate "ordering" and evaluation (Boltanski and Thévenot, 2006: 14; Boltanski, 2012: 60). Not unlike Bourdieu's habitus and habitat, competences and conventions are mutually constituted, but unlike Bourdieu it is a will to justice grounded in a good pertinent to a situation, not to power grounded in groups whose members occupy particular positions, that has primacy. ${ }^{4}$

Boltanski glosses the project this way: "to clarify the principles of justice on which people rely when they engage in critiques or produce justifications, and when they make explicit the operations by means of which they establish the well-foundedness of their assertions by using proofs to relate them to reality" (Boltanski, 2012: 34). Justification is not ideology; it is a morally effective ground for agreement about the 
"relative size or worth (la grandeur) of the different beings present in the situation" (Boltanski \& Thévenot, 1999, p. 363). Actors are endowed with capacities for morally persuasive argumentation that result in "active agreement" (Boltanski, 2012: 43). Boltanski writes:

The work of model creation seeks to reconstitute the competence that actors must be able to enact in order to produce arguments that are acceptable 'convincing'- to others in specific situations; in other words arguments that can support a claim to intelligibility and that are endowed, too, with a high degree of objectivity and thus of universality (Boltanski, 2012: 33).

Actors' competences are understood as cognitive, an ability to recognize, align and deploy categories and objects in ways that justify, that are agreeable and legitimate to all (Boltanski, 2012: 33). ${ }^{5}$ Grounded in the problem of "coordination," in OJ Boltanski and Thévenot explained that they were attending to "the cognitive ability that allows human beings to establish associations among things that count, to identify beings independently of circumstances, and to reach agreement on forms of generality" (Boltanski and Thévenot, 2006: 32). ${ }^{6}$

Displacing Pierre Bourdieu's economistic objectifications incorporated by agents differentially positioned vis à vis different kinds of capital in agonistic social fields, fields animated by instrumental interest in their distribution and returns to the forms of capital operative in that field (Bourdieu, 1984, 1998, 2001), Boltanski and Thévenot posited a morally animated public world grounded in common goods, goods that presumed the ability and interest of persons to justify and critique social arrangements based upon 
metaphysical values tied to conventions that qualify persons and objects as exemplars of these goods (Boltanski and Thévenot, 2006).

The social world and the actors within it are organized around particular common goods - goods that are plural, incommensurable and potentially in conflict. It is an immanently moral world, not reducible to a hidden machine language of domination and violence. Boltanski and Thévenot took the moral ideal of justice seriously, not as external legitimation, but as part of the internal constitution of social coordination under conditions of uncertainty. Common goods are bases of social coordination, not their legitimations. "The social sciences have... leaned on relativism in order to free themselves from the authority of values," Boltanski and Thévenot wrote, referring to the ways in which critical sociology made actors' moral claims illusory and reduced their actions and their claims to expressions of the general equivalent of individual or group interest or power (Boltanski and Thévenot, 2006: 343-344; Boltanski, 2012:19-20). Boltanski and Thévenot refused to flee from value with its implication of normative consensualism into impersonal powers objectified in structural arrangements, positional capitals grounding individual interests that establish trans-situational equivalences, or into transpersonal cognitive regularities as in behavioral economics. ${ }^{7}$

Theirs is a political theory of collective life, a republican theory. Justice is the meta-value theoretically commensurating distributions of variable goods. There is a “constant anxiety” about justice (Boltanski and Thévenot, 2006: 37; Boltanski, 2012: 25). Common goods do not legitimate inequities; they afford them by the qualifications through which they are made manifest. Justice is known not through value, but through its manifestation as worth. Polities are unstable both because of the contingency of 
justification of these distributions, the state of worth, and which order of worth is pertinent. Critique emerges through the optic of justice. But injustice is not inequality per se. Injustice is a "division of material and immaterial goods that does not respect the legitimate order of worth among persons (Boltanski, 2012: 26). Justifications work if they conform to the conventions by which worth is qualified, to the evidentiary outcome of "reality tests" which they afford, and the material formatting of the situation adjusted to the good and delimiting its operability.

New Modes of Action: Fairness, Violence and Love

Justice is only known through social conflict. And those conflicts, Boltanski recognized, do not necessarily eventuate in an agreement, or even a compromise. Provoked by his study of disputes that did not resolve themselves through "tests" using agreed-upon principles of equivalence, Boltanski sought to explore modes of action beyond the limits of justification, beyond equivalence and justice, beyond the juridical proofs and the selfreferential language games played out in the conjoint deployment of common goods and valorized objects in which actors test the relative worth of persons under conditions of critique (Boltanski, 2012: 67).

Soon after the French publication of Les economies de la grandeur (1987), which was revised and published as On Justification (Boltanski \& Thévenot, 1991), Boltanski grappled with violence and love as that which disrupts or surpasses the equivalence, or generality, provided by common goods undergirding justification (Boltanski, 2012 [1990]). In Love and Justice as Competences, Boltanski restated the political grammar, 
"the stable forms that appear in the actors' accounts" (Boltanski, 2012: 31) by which polities are formed through the joining of metaphysical common goods as "principle[s] of order", values with which people identify, on the one side, and material conventions for the evaluation of their worth in terms of this value on the other (Boltanski, 2012:13-14).

In Love and Justice as Competences Boltanski delineated three other modes of action beyond the ambit of justice: fairness, violence and love. ${ }^{8}$ Each of these now four modes, he argued, are self-sustaining, with a "tendency to persist" until disrupted by an encounter with a person who is "installed in another regime" (Boltanski, 2012: 74, 152). If $O J$ was centered around the question of worth "attached to a situation," this text centers on dyadic relationships between persons (Boltanski, 2012: 48, 94). Justice and fairness, regimes of conflict and peace respectively, are organized around generalized equivalence, the first through cognitive competences manifest and deployed in loud disputes over relative worth that are resolved through tests, the second organized tacitly through the organization of objects in a "silence of equivalence" (Boltanski, 2012: 92). Drawing on the Latourian tradition, objects, which are essential equipment to conventions of worth, are deposits of past controversies over worth, materialized agreements establishing "equivalences in an irreversible form" (Boltanski, 2012: 92).

In a regime of fairness people treat each other as if they were things. Indeed, in a regime of fairness, they are things.

$[\mathrm{I}] \mathrm{n}$ this regime people develop the inner being that can harmonize with things because it has the nature of things: people confer on themselves and on others the character of irreversibility that qualifies objects according to their metaphysics (Chateauraynaud (1991)), and they do not use language to call into question the 
equivalences inscribed in the stability of things and in the steadfastness of people when they present those aspects that are constant in themselves (Boltanski, 2012: 70).

It is the objects, not a structure of positions, nor material practice, that stabilize the situation. "[C]oherent universes of objects" undergird tests based upon a particular principle of equivalence (Boltanski, 2012: 99). ${ }^{9}$

The status of the object differs in a regime of justice and fairness: In the first, one speaks for the object; in the second, the object "speaks" for itself, that is, silently, as do train-tracks or high-frequency algorithms. Nothing need be said; things work this way. Or, if it is said, it is only a local and sketchy account that neither totalizes, nor rises to an explicit reference to the principle of equivalence. And in a regime of justice when people speak for things, it is valuation, and evaluation in particular, that drives control over things. ${ }^{10}$ The co-implication of domination and value formation from which Bourdieu sought to develop a generalized political economy is unthinkable within this approach.

Violence and love: In these two modes of action, there is no equivalence. Boltanski and Thévenot could thus continue to sideline them in On Justification, published four years later. Objects and persons are "inaccessible" to language. In both the urgent time of the now presses for action. In both the conventional articulation of persons and things does not obtain. In violence, things are not "human things," becoming rather unknown "forces"; in love, persons have primacy, neither bound to nor conditioned by things (Boltanski, 2012: 69, 72-73). In violence it is only things deployed in contests of force that count as such; persons are rendered mute and material, not unlike their thingly 
quality in fairness. In love, things have no bearing; only singular persons count. One gives things in order not to be them (Boltanski, 2012: 140).

\section{Through Love: The Return of the Religious?}

Boltanski's extrusion of love from justice and fairness derives from his identification of love with the Christian category of agape, a desireless, present-oriented modality that "expects nothing in return," that recognizes no standard of equivalence, responding only to the singularity of the "neighbor" (Boltanski, 2012: 110-114). Without equivalence, and thus beyond calculation and code, agape, Boltanski writes, is historically grounded in the Christian's deity's incarnational gift and the "expectation of parousia," Christ's second coming (Boltanski, 2012: 114). Agape is the ground of the "new law" inscribed in the heart, dependent on intention not on act, as opposed to the “old law” of Moses (Boltanski, 2012: 113). Boltanski’s love is a secularized Christian agape.

Boltanski's appropriation of theological sources for conceptualizing the social would also be present in $O J$ in his and Thévenot's use of St. Augustine City of God to posit the cite of inspiration, of which it appears to be a form (Silber, 2014). Boltanski maintains the same stance to Christian theology and human love that he and Thévenot did, for example, to the relation between Rousseau's understanding of the general will and common goods underivable from the aggregation of private interests operative in French republicanism. Philosophical texts offer clarified models for world-making in part because they made our world. Boltanski on the one hand asserts that he intends to cut 
love away from its "supernatural dimension." ${ }^{11} \mathrm{He}$ will, he says, "deploy the intuitive understanding of agape that I believe all of us share," an understanding that is already "known in practice" (Boltanski, 2012: 101-102). He writes:

...the supernatural foundation can be bracketed here. For if the new law cannot do without the eschatology of judgement, the fact remains that the expectation of parousia, or the second coming, does not modify the modalities of the relationships among human beings that it prescribes for the present (Boltanski, 2012: 114).

Boltanski aims to construct love such that it can be re-inserted into "the theological corpus" (Boltanski, 2012: 101, 116). The implication is that we live in a Christian world, either because the world is Christian or because Christianity only clarifies what was already there. ${ }^{12}$ Agape is a giving in the present without any expectation of return, untainted then by the cycle of exchange, by norms of reciprocity or self-interested instrumentalism, unhinged from the retrospective claims accompanying justice, purified of the prospective desires of eros. Agape recognizes no human worth.

It is not that Boltanski the person is a Catholic sociologist; it is that his sociology is Catholic. His love is the secular form of Christ's "new law," inscribed in the heart, not in legal forms of a new holy Israelite nation (Boltanski, 2012: 113). Christian love is the source of charity, not justice, tzedakah ${ }^{13}$, miming God's gift of salvation through the sacrifice of his Son, not of the law revealed to his beloved prophet Moses. Agape, Boltanski argues, recognizes no law, no value, not even humanity. Agape rather depends, like Christian grace, on an unwilled individual intention, an allowing oneself to be possessed, not a behavioral adhesion to the law (Boltanski, 2012: 113-115). Boltanski identifies agape as an unbidden desire to give, a passive possession by love (Boltanski, 
2012: 156-157). In this form of love one does not compare, neither looking backward nor forward: One acts towards the person one sees before you now. Boltanski's love is modeled on the unilateral gift, where objects given are tokens of love. It is enacted and observed in instants of giving; it neither anticipates reciprocity nor remembers past nonreciprocities (Boltanski, 2012: 112, 154). Like the Christian messiah, it is figured as an event. What the other does or does not do is not a constituent of love. Agape, he writes, "is not based on an interactionist schema" (Boltanski, 2012: 112). In agape there is no equivalence and thus none of the accounting necessary to reciprocity that characterizes friendship, to regimes grounded in self-interested exchange, or to justice.

\section{Boltanski's Love is Not Justice}

Boltanski's love is, and cannot be, public, cannot therefore operate as a constituent of justice. For Boltanski love is not only a bride without a groom, it is stripped bare - of desire, of language, of publicness, a manifestation of an exceptional will to give. Boltanski's secularization is selective. He argues that love is irreducible to discourse. Never mind the originary status of the word, the theological connection between the divine Word and the human capacity to love in the Christian tradition, that the Word is a medium and manifestation of divine love, a seminal animation, that Judaism and Christianity are narrative religions. This is not to mention that in the Rabbinic sources the Hebrew letters are understood as the substance of the Godhead (Holdrege, 1995). ${ }^{14}$ 
In Boltanski's formulation those in love do not and cannot use the language of love self-referentially without risking love's destruction. "The theory of love is addressed to those who are not in love (Boltanski, 2012: 102-101, 150). ${ }^{15}$ Boltanski makes love into an asocial capacity, not a social praxis with its own discursive and non-discursive equipment, whether prayers and hagiographies, saints and icons, agape feasts, alms bags and collection plates, or verse, songs, novels, ribbons and wrapping papers, therapies, park benches, snapshots and portraits, criminal and familial law, diamond rings, red roses, hair-clippers and lip-gloss, not to mention its faces, fingers and genitals. An unequipped love is at odds with Latour's understanding of the subject as a gathering of "entities," or "plug-ins," and specifically with regard to love as a competence (Latour, 2005: 207). ${ }^{16}$ Latour writes:

Take, for instance, love talks. If you doubt the efficacy of this kind of transportation, do the experiment. Try living without them for a bit and see how fast 'you'-yes, the primeval 'you'- will simply wither away. Even love, love especially, can be construed as that which comes from the outside, as a somewhat miraculous gift to create an inside. And it is certainly the way it has been traced in poems, songs, and paintings, not to mention the countless retinue of angels, cherubs, putties, and arrows whose objective existence, yes objective, should also be taken into account. Even love has to have its vehicle, its specific techniques, its conduits, its equipment just as much as a trading room, a headquarters or a factory (Latour, 2005:212).

For Latour, love, like justice, is a competence that draws from the outside, subjectivizing in a particular register. For Boltanski, in contrast, love is not a formatted 
competence; it is a phenomenological form exceeding any law, any code, any equipment. ${ }^{17}$ Love does not measure, does not justify. Love relies, following Kierkegaard, on the "authority of the act" (Boltanski, 2012: 118-119). It is, Boltanski states, a secularization of the "new law" "inscribed in the heart," whose "validity," depends on the intention of the actor, a variant of Weber's approach to value rationality, likewise grounded in subjective commitment without regard to consequences (Boltanski, 2012: 113). It is a Pauline Christian deconstruction of the law, an outside to worldmaking conventions. Love, for Boltanski, is certainly not an exchange, not even an interaction, nor a communion, a self-expressive giving of oneself, an historical creation of a we. ${ }^{18}$ One neither enters nor exits love through one's will. Love does depend on a desire "firmly maintained on the boundaries," an involuntary and unbidden desire to give, (Boltanski, 2012: 153-154). As long as the gift is reciprocated, one does not recognize the desire that powers it. Agape depends on a "collective use of the faculty of forgetting" of counter-gifts. If Bourdieu reduces the gift to misrecognized exchange, Boltanski here reduces the gift to a misrecognized desire to give.

For Boltanski, justice, and hence the justification that stands at the center of his work with Thévenot, depends on equivalence. Love, which suspends equivalence, stands outside the walls of justice. Boltanski follows in the tracks laid down by Hannah Arendt, who argued that love by its destruction of the in-between afforded by objects and by the inadequacy of language to it, could not accede to the public sphere. Materially and discursively unequipped, how could love be otherwise? In The Human Condition, Arendt wrote: 
"[L]ove, in distinction from friendship is killed, or rather extinguished, the moment it is displayed in public...Because of its inherent worldlessness, love can only become false and perverted when it is used for political purposes such as the change or salvation of the world" (Arendt, 1958, p. 52).

Love rather thrives on particularity and incommensurability. "Agape can be active only when it is aroused by the presence of unique persons... (Boltanski, 2012: 112). It is only, Boltanski maintains, a regime of agape that brings "persons as such to full realization," or, following Kierkegaard, "the person one sees" (Boltanski, 2012: 72, 116). Boltanski relies on Christian theologians and philosophers, not on the practice, nor experience, of Christians, to construct his model of love.

Contra Boltanski, it is arguable that in the orthodox Christian tradition, agape is not a propitious platform for singular personhood. Examining the Augustinian theological tradition, the orthodoxy for most of the history of Western Christendom, Boltanski's carrier for love reveals itself as, in fact, singularly void of singular persons. In Augustine's Christian anthropology, dyadic love and the Church community are coimplicated. The will to love derives from a God who is love as manifest both in his creation of humanity and the sacrifice of His only begotten Son. Divine incarnation is essential to this earthly love, to loving the earthly other. An individual turns inside the self to discover him or herself whose divine source, "the life of lives," is present within, "more intimate to me than I am to myself" (Augustine, 2009:62). The community, as a body of Christ in "defense against the world," is formed through the love of doubly equal others, equal in their sinful generation from Adam and in their redemption by God's grace, an equality which is only realized in the humble turn of each isolated individual 
towards God (Arendt, 1996, pp. 102-106, 108).

The Christian community is not formed out of a relationship between singular others, but out of one's “absolute isolation” before God (Arendt, 1996: 110-111). Caritas, the selfless giving to the neighbor, is a necessary consequence of divine grace, each loving the love in the other potentially revealed to all (Arendt, 1996: 106). One must love the other because of your sameness in sin and redemption. One loves the other not for him- or herself, but indirectly as a way to love God, and as an imitation of God's love for each of us (Arendt, 1996: 110-111). One loves the created soul, the source of his true individuality, not the generated body of a mere "being of the human race." (Arendt, 1996: 111). "The individual is completely forgotten over this community," Arendt writes. "The individual has ceased to be anything but a member and his entire being lies in the connection of all members in Christ. Mutual love becomes self-love, since the being of one's own self is identified with the being of Christ, that is, with the being of the body in which it shares as a member." (Arendt, 1996: 109). One loves the other as a way of loving the love in oneself and the other. Christian love is located in our creaturely sameness, born in sinfulness, not so different than the animated thingness to which we are subject in industrial and market worth.

This is not to say that Christian sameness is not an appropriate religious anthropology through which to build a mass society of equivalent beings, each even endowed with rights. It is the generality of Christian love, its inclusiveness and universalizability, its way, according to Clement, of "deifying humanity," that makes it an institutional resource for modernity (Pagels, 1989, pp. 39, 103). Christian love not only provides a basis for social justice, for the care offered to anybody because we have 
all been formed in the image of God, but for a spiritual equality and liberty, upon which the loving of others and self-government can both be founded.

But this is not the analytic path that Boltanski follows. He ties love to singularity which he opposes to a regime of justice ${ }^{19}$ It is arguable that justice, while grounded in equivalence, does not exclude singularity. Singularity is a critical element not only in love, but in justice, and, by implication, in the juridical understanding of justification elaborated by Boltanski and Thévenot. Derrida has pointed to the impossible approach to the incalculable singularity of the other as the ground of justice, an approach or attunement essential to the decision on the applicability of the law, a mandate nonetheless integral to the law's operability (Derrida, 1998). ${ }^{20}$ For Derrida there is a "religious" ground to every social bond, both in the premises of the address and the obligation to respond. The "desire for justice" is grounded in an abstract messianicity, in the unexpected and unscathed other, in the faith and sacrality immanent, but invisible, in all social life (Derrida, 1998, p. 18) ${ }^{21}$ Friendship, generosity, neighborliness and love are the life-world forms out of which we compose justice, forms that enable us to imagine and desire it. Justice here involves more than calculable equivalence; it also requires an incalculable ground for the demand for equivalence, not unrelated to what Boltanski and Thévenot identified in their polity model as the "principle of common humanity" linked by a common good beyond the "particular happiness of each person," and its elemental requirements of human dignity, an "identical power of access to all the states that we shall designate (Boltanski and Thévenot, 2006: 74-76). In this optic justice is an unassimilable, untranslatable figure that love takes within any institution, not just the law of the nation-state. If law depends on an incalculable justice, an invisible institutional 
substance only known in practice, but upon which that practice depends, and if the religious structures undergirding its possibility also afford hospitality and love, that implies that there is a pathway by which love can be immanent to justice, an outside necessarily inside (Friedland, 2009). The way in which Boltanski has constructed love, as a Christian gift-giving and recognition of singular others, precludes love's social productivity, as a ground of justice and liberty.

\section{The Erotics of Boltanski's Justice}

Boltanski aligns justice with eros, with the management of possessive desires, not the self-givings of love. He can make this move only because he cuts love away from erotic desire. Here again, we see the intellectual imprint of the historically dominant Christian understanding. This Christianity is clear if you compare it to that of the Jews. The Israelite relation to its God is suffused with desire, indeed erotic desire, manifest in the prophets and the Song of Songs, that of a bride to her husband, a woman to her lover. Boltanski's construction of agape is a particular Christian understanding, a Pauline (St. Paul) and Augustinian reading of Christianity, in which desire is headlined as divine punishment for human rebellion against God's authority, an embodied mark of original sin passed on through the male seed, a theological racism. One truly loves in spirit, not in body.

Boltanski's agape is an antique form, a carry-over of an outdated orthodoxy. This orthodox understanding has been contested throughout history and repudiated by the Latin Church, most notably - in terms that replicate Emperor Julian's oppositional 
understanding of erotic desire as a "vital fire" -- by Pope Benedict in his very first encyclical, Deus est Caritas. Steeped in Greek paideia, Benedict invoked eros by name as a spiritual expression of divine love, as a medium that can provide us access to "that beatitude for which our whole being yearns." Eros, he wrote, provides a "certain foretaste of the Divine," indeed "tends to rise 'in ecstasy' toward the Divine." This ascending erotic love is reciprocated by God, he writes, "a lover with all the passion of a true love." Benedict was drawing on the formulations of Pope John Paul II, who early in his papacy had spoken in his general audiences about the sexual union of man and woman as an incarnation of communion, as a mutual gift through which people took on "the image of God."22 This very Christian prospect of the supplementarity of eros and agape is not possible in Boltanski's construction.

If Boltanski's love is wordless, his erotics are all too worldly and profane. In his social topology, eros is situated in the privative and exclusionary worlds of worth. If love suspends justice, eros is its engine in Boltanski's formulation. Love is identified with a desire to give; eros with a desire to have. Eros, unlike agape, is "awakened" by "value of its object" (Boltanski, 2012: 111). Severed from love as agape, Boltanski joins eros to the world of equivalence, to "feelings of deprivation" vis a vis "objects of desire," and thus to justice as a mode of action (Boltanski, 2012: 107). For Boltanski eros, presumably following Diotima in the Symposium, powers the transom between possession of the particular and the love of the general forms of the good. In Boltanski's gloss desire for possession of the particular ascends to the equivalence undergirding the desired.

Boltanski will spend his entire career keeping desire analytically at bay, a source 
of suffering, the purview of psychoanalysts, not sociologists.

An object, such as a person, can be considered in her singular dimension hence become the object of an intense affective investment, an exclusive passion (...). But this way of conceiving the relation between human beings and objects is not of sociological matter; it is the topic of disciplines that refer to unconscious actions, such as psychoanalysis. (Boltanski and Esquerre, 2014: 23) ${ }^{23}$

The entry of desire and passion in capitalism - through the artistic critique - is also said by Boltanksi and Chiapello (2007) to be at the origins of the distress of human beings. At first the sources of critique suggest an incommensurability with the worlds of worth grounding justification in $O J$, carried by an indignation deriving from a metaethical violation of "humanity." The artistic critique, in particular, oriented to the loss of "meaning," of "what is beautiful and valuable" seems difficult to locate (Boltanski and Chiapello, 2007: 38). ${ }^{24}$

Although the concept of "artistic critique" comes from Chiapello's previous work, “Artists versus managers," published in 1998 and not modeled on Augustine's City of God, the features displayed by the artistic critique in New Spirit also echo the specifications of "the inspired world" of $O J$, a world based on internal transformations, without equivalence, animated by "feeling and passions." Boltanski and Thévenot described the "passion" thus: "The passion that moves them instill in them at the same time a desire to create -a desire awakened by inspiration - along with anxiety or doubt, love for the object pursued, and suffering" (Boltanski and Thévenot, 2006: 159-160). In the inspired world, "natural relationships are relationships of creation. Each being creates and allows itself to created by others" (Boltanski and Thévenot, 2006: 162). 
This description of the artist is also found in Chiapello's earlier work where she opposes the "genius", "singularity", "sacré", "gratuity" and "creativity" of the artist to the "work", "standardization", "interest", "utility" and "predictability" of the manager (Chiapello, 1998, p. 45). Through the projective city, with its flexible and creative project heads who model themselves as artists whose "vision generates enthusiasm," who inspire, rather than motivate, their workers, capitalism gives a delimited access to these feelings but only through a network of connections that operate not through creation, but "recombination" (Boltanski and Chiapello, 2007: 81, 112-114, 129). The same singularity Boltanski identified with agape is transposed to the artistic critique in New Spirit. Boltanski and Chiapello thus build their critique on this divine quality of man, on his or her desire and ability to create, including himself. Justice stands as the mediating figure between the systemic, insatiable eros of capitalism and the agape, now identified with the creative needs that each of us carry within. And once again it is love, with its link to the singular and the incommensurable, that might be the medium by which to transport human self-creation to the world.

Boltanski and Chiapello's text can be read as continuous with Boltanski's utopian apotheosis of agape as a secularized Christian critique of the equivalences of justice in Love and Justice. This same suspension of equivalence is at the center of the Marxism he laid out there, marginalizing the "industrial" critique of scarcity, emphasizing rather Marx's Gotha program in which it is the need to create as an end in itself, unhinged from monetary equivalence, that is the ground and telos of radical critique (Boltanski, 2012: 132-138). Once again it is creation, not production, that has primacy, creation as a selfgiving identified as the divine outside, that suspends equivalence and affords authenticity. 
Where individual differences have become commodified, counter-hegemonic practice depends on a critique of production, or "fabrication," itself, a return to creation as selfgiving "without any other intention than making it" (Boltanski and Chiapello, 2007: 449). This includes the "production" of self (Boltanski and Chiapello, 2007: 154). As in Christian agape, it is again not the other, not the object given, but the intention that has primacy. And once again it is eros as insatiable desire which is the devil's work, that "insatiability" identified not with human beings, but with capitalism itself (Boltanski and Chiapello, 2007: 487). There are several ways one might explain this. Boltanski's exclusion of eros might be read as an indicator of a secularized theological commitment, as a way to localize - at a microscopic scale -- a desireless heavenly city on this earth. It can also be read as a parallel secular utopian hope à la Marx for a social order in which the desire to create, not to possess or produce scarce goods, predominates, which will later become a dominant theme in his analysis of the "new spirit" of capitalism (Boltanski, 2012: 133-138). It can also be understood as a liberal economism, in which eros is sublimated into an incorporation of the utilitarian premise of wanting more.

Boltanski builds his modes topographically, as territories with boundaries and passageways. While the work has the merit of exploring violence and love, Boltanski locates them in an unbelievable extra-social territory, last exits from sociological reality. The first hint of the problem is in his treatment of emotion, which, for him, always marks a frontier or an externality. Boltanski's modes of action are known to persons through their distance from each other. This is particularly clear with wordless love: "It is only in the tension it maintains with justice that love in the sense of agape can carve out a path towards expression" (Boltanski, 2012: 150). With "something incommensurable" 
between them, the transom between modes of action is hot and heavily trafficked, pulsing with emotion (Boltanski, 2012: 76). Boltanski derives that heat, like Mary Douglas situates danger, in no-man's zones and liminal areas between the modalities. This is where emotion lives.

Love, like justice, fairness, and even violence, Boltanski maintains, are without emotion, characterized respectively by peace, serenity, placidity and coldness (Boltanski, 2012: 162). Theories of love, for example, are neither justifications nor clarifications of a base of equivalence; they are rather mediations by which to the make the fearful passage into love, "assuring them that they will come through it alive" (Boltanski, 2012: 103). But emotion is not integral to Boltanski's modes of action: It is the affect of entry and exit, of persons' experience of the limits of a modality. Emotion rather is the bodily mechanism by which traces of one regime get smuggled into another, a transposition analogous to the way private interests carry the traces of inadmissible common goods in OJ (Boltanski, 2012: 162). Demands for justice, for instance, particularly those powered by indignation, refract a loss suffered in agape, an "unformulable demand for recognition of the person without limits" (Boltanski, 2012: 76). Reciprocally, the limits of justice are inscribed through improbable parables in Biblical narration - as in the last hired, and equally paid, vineyard workers - expressing the concrete singularities operative in agape (Boltanski, 2012: 126-128).

It is arguable that emotion, a corporeal state of being that exceeds language, is not located just between modes of action. It is internal to them, not only in love and violence, but justice as well. Justice depends on values grounding equivalence. Emotion is critical to their valuation (Friedland, forthcoming; Friedland, 2016). In perceptual philosophies 
emotions are bodily, or affective, experiences of a world represented according to a particular value (Todd, 2014). ${ }^{25}$ Emotions visibly articulate non-intentional bodily affects and values as intentional objects, sadness and loss for example. ${ }^{26}$ However, in the phenomenology of the emotion it is not a knowing of the value, the intentional or "formal" object, which cognitively grounds the emotion, but the specific object to which a person responds (Todd, 2014: 705). Emotions do not operate as reactions to values imposed on facts. Rather emotions are themselves "modes of access" to value (Teroni, 2007: 405). This would place emotion - in the singularity of its operation - within, not between, modes of action that depend on equivalence. Such an understanding opens up the possibility that love, including the passionate and the bodily kind, is central to the operability of value, and by implication, worth, not a trace of its inoperability (Friedland, 2016).

\section{The Need to Restore Love as a Pathway to Justice}

Constituted by its difference from self-interested, instrumental exchange, from a tacit coordination, Boltanski's model of agape is tied to an economistic subject-object dualism, to love as a giving of gift-objects. What distinguishes agape is first that it does not acknowledge the self-interested quality of the desire to give and second that it neither acknowledges nor measures value, neither of its object nor of the objects given (Boltanski, 2012: 111). ${ }^{27}$ Boltanski's love does not recognize value because he models love on the gift, on the present-oriented giving of objects without regard to self-interest or the equivalence of reciprocity. Love is known economistically as its negation. 
In Boltanski and Thévenot's understanding justice is about worth. Boltanski argues that love does not take the worth of objects or persons into account, that it fulfills itself in present action and thus excludes the calculation of equivalences. In his framework, justice is linked to the instrumental, egoistic desires of eros. This does not mean love does not take value into account. This is true both in a theological and a sociological register. While agape may suppress debts to persons (Boltanski, 2012: 114), in the Christian formulation human love mimes the infinite debt we owe to the divine as the source of our life and our after-life, our salvation, unpayable and beyond equivalence. Our own gifts are pitiful against such a debt. In this divine economy the will to love derives from this infinite debt: To love is to realize the divinity within us, that we are made in the divine image, that we are not the source of our own lives. To love is to be true to the way we have been produced. To love is to acknowledge the unpayable debt, to give as God gives, beyond comprehension, without warrant, beyond calculation. It is to acknowledge, to be afforded by, to accept and participate in this love.

What Boltanski means is not that love does not acknowledge value, but that it does not acknowledge worth, that it does not focus on the worth of its objects, the objects given or the object of one's love. Luther, who understood one's worldly calling as the way to practice "brotherly love," argued that, in Weber's words, "every legitimate calling has exactly the same worth in the sight of God" (Weber, 1958b, p. 81). Christian love is indifferent to the differential worthiness of its objects, to rich and poor, to pious and sinner. But to love, as Boltanski notes, one must presuppose love (Boltanski, 2012: 156). Indeed, one must love love. Love is a value, a value without which the social world would be insufferable, a world in which we would not be willing to live. Loving is indeed 
an objectless practice, a practice of giving that has a non-arbitrary relationship to this metaphysical value, that is done not only for its object, the beloved, but for the sake of love itself. It is not that God is love, a Christian formulation, but that love is a god, a sociological formulation.

Love - like market value, property, national sovereignty, knowledge, art, security, kin, or God--can also be conceptualized not just as a value, which identifies it as a subject-centered valuation, but as an institutional substance, substance in the Aristotelian sense, that which makes something a "this," a no-thing and no-body grounding an institutional logic, a meaningful regime of practice that subjectivizes and objectivizes in determinate ways (Friedland, forthcoming). An institutional substance has the analytic attributes of a god, a conceptualization consonant with Max Weber's polytheistic understanding of modernity's value spheres (Friedland, 2014, 2016; Weber, 1958a). But what kind of God? An institutional substance accords, in large part, with Jean Luc Marion's re-imagining of God as the given (Marion, 2012), as opposed to giver or gift, an irreducible essence before object and interpretation, which calls us to ourselves, to which we owe the very forms of our social being. In Marion's notion of the divine as givenness, givenness is "the essence of the phenomenon," in which the being of "intentional objects" is appearance, an appearance that is given (Wolfson, 2015, p. 172) .

For Boltanski, God is The Giver. Boltanski implicitly treats the Christian God as a highest Being, who initiates exchange patterns that become general forms. If we supplement our imagination of God with the apophatic tradition, God is the general equivalent, not just the giver of our gifts, of our lives above all, but the given, that which appears independently of our wills, what gives us to ourselves, which animates us, around 
and through which we form our wills. The apophatic deity, as given, can never become an actual gift, for then, according to Marion, it would be assimilated to the logic of exchange of donor, gift and recipient, and therefore no longer a gift. ${ }^{2}$ The phenomenological paradox of the gift is that its givenness cannot appear in the actual object world. ${ }^{3}$ The divine as given only appears by being invisible, as an "unconditional immanence" (Wolfson, 2015: 171-172).

In loving we participate in a divine givenness. The values of modern life, which we have termed institutional substances (Friedland, 2016), and Weber termed value ideas, enable us to act in their name, in their image; they afford the forms of our practice and our being. And we only know them through our practice and our being. If we understand love as a value, it would be first the value, the given, that one loves, desires, evaluates, and secondarily the beloved as the "object" whom one loves. Moreover we can only love in particularity, the kind of particularity to which every mode of action is subject, a particularity consonant with the way in which emotion provides a portal to value. One defends this boundary and the border guards with the creased pants and machine guns, buys this piece of property at the corner, this cobalt blue shirt in the shop window, knows these scientific regularities and super-cardinal ordinals, loves this person whose laughter is her strongest muscle. ${ }^{4}$ Boltanski rather puts love through the test of the exchange of things, to gifts given without expectation of return. If one centers on value,

\footnotetext{
${ }^{2}$ Marion writes: "Either the gift appears as actual but disappears as a gift, or it remains as a pure gift but becomes unapparent, nonfactual, excluded from the instance of things, a pure idea of reason, a simple noumenon incompatible with the conditions of experience... Either the gift remains true to givenness but never appears or it does appear, but in the economy of exchange, where it is transformed into its contrary to be precise an exchange, a given that is returned..." (Marion, 2005, p. 104, cited in Wolfson, 2015: 171).

3 "The major aporia of the gift derives from this paradox: the gift given can appear only by erasing in its phenomenon its giver, the process of its gift, and, ultimately, its entire gift-character." (Marion, 2011, p. 78).

${ }^{4}$ The muscularity of laughter taken from Toni Morrison interview, New Yorker Festival, October 2, 2015.
} 
rather than worth, on the given, rather than the gift, the generality of love comes back into view, comparable to justice as an actionable good, a good grounding the instrumental, action carrying vectors of desire, hungers whose possessiveness can never accede to the good that affords them. By starting with value, rather than worth, agape and eros correlate and complement, not contradict and impede.

Boltanski centers his analysis around the gift, as opposed to the given, to the givenness of love and life. Love is a given to which one must give oneself. "One loves loving and, therefore, a person whom one can love," remarks the systems theorist Niklas Luhmann (Luhmann, 2010, p. 32). One falls in love, Luhmann writes, "because of loving love." Love is a given, not a gift, that gives us to ourselves, that offers a way of doing and being that can never be reduced to the having of the object of our love, nor to the objects given in our practice of loving, nor even to the practice of giving. Any and all of these reductions are forms of idolatry, a reduction of the ultimate value, the institutional substance, to conventional practice, to particular relationships between subjects and objects, god to rite. Love, as Diotima argues in The Symposium, is a daimon, a spirit between the gods and humans, not a being, but a medium between humans with their corporeal desires and the gods, understood as an activity in the ancient Greek. ${ }^{5}$ Giving, like voting vis a vis popular sovereignty or democratic representation which likewise also depends on an irrational self-giving for the good of representation, is a practice that not only presumes, but produces love, if we do not locate it just in the subject's intention, nor in the practice, but also as an institutional substance which we can never access. These

\footnotetext{
${ }^{5}$ This has a kinship with the original understanding of utilitarianism as eudaimonia, typically translating happiness, but involving the conjoining of the good, $e u$, and a daimon, or divine spirit.
} 
practices produce what can never be possessed, that which we can never have. ${ }^{6}$

Because Boltanski has made justice about worth, and not value, there is an impassible incommensurability between justice and love. In a regime of justice, we would argue, one does not speak for objects, or "beings," one speaks, in fact, for the good that grounds the equivalence aligning persons and objects. Objects are an occasion for speaking of the good. It is, as Boltanski, remarks, really a "metaphysical capacity," "a pre-existing definition of what constitutes the value of things and persons, a scale of values that requires clarification in the case of disagreement" (Boltanski, 2012: 47). One cannot test value just as one cannot test God, which is why tests between orders of worth are necessarily tests of strength, potentially occasions for love and violence, moments of instituting. And one can love the value, the substance, the god, giving oneself, as Boltanski himself points out "even also in the workplace... without counting and without calculation, setting equivalence aside (Boltanski, 2012: 161). ${ }^{28}$

If we understand love, and in the Christian tradition God, as the ground of that love and hence the ultimate value (in loving God, one loves love and vice versa), love looks a lot like justice, a loving the givenness that affords our modes of humanness, a loving the good that allows us to justify ourselves and others -- and not just in moments of critique, an immanence that affords both our desire to possess and our possession by those goods, our co-implicated instrumental and value rationalities, our ways of being with in which we love each other through the goods we love in common. Why not assume that just as the silence of fairness is a practical immanentization of the common goods grounding justice, so the apparent wordlessness of love depends on an equipped

\footnotetext{
${ }^{6}$ This was Pausanias' understanding of heavenly eros in The Symposium, who used both the concepts of practical conventions and test of lovers, as a "voluntary slavery... which aims to produce virtue" (Plato, 1999, pp. 14-16).
} 
world - in our sensuous, human bodies, at least -- of the good of love in whose image we form our intimate, and perhaps our public, lives. Like fairness love becomes subject to justification when one falls into evaluation, which does not necessarily mean that one "falls out of love." These are tricky questions for which we do not have answers. But it is clear that we must pay attention to when worldlessness is a reflection of the immanence of institution and the silence that implies as opposed to something which simply cannot be said because it is incommensurable to the codes and practices of the social world, and thus beyond or outside of institution, a miracle in which we insist on believing.

Love, passionate love too, provides a pathway to the instituting of justice. It is there in republican thought, in the works of Jean-Jacques Rousseau, the very author Boltanski and Thévenot used to distill the principle of equivalence in a civic world: the relation to a collective body. Rousseau's writings -- published in quick succession -Julie, ou la nouvelle Heloise (1761), Emile, ou De l'éducation (1762b) and Du Contrat Social ou Principes du droit politique (1762a) -- played a critical role in preparing the ground for the French revolution. For Rousseau, the very concept of the revolution began as Julie's erotic turning to her socially inferior tutor, to what Rousseau understood as love's powerful, but vital, illusion, linked to a turning towards a refigured God, that was the initial referent for what is also people's capacity and demand to be solidary and sovereign. Rousseau's revolution" as Matthew Maguire puts it, “...is the radical and explicit attribution of value, beauty, and attachment among human beings in love, in common life with others, and with God, to illusion or the possibility of illusion...." (Maguire, 2006, p. 124). ${ }^{29}$ Passionate love was a template for the moralized will 
necessary to the love of a lover, a god and a people, all driven by a desire to be given oneself in the eyes of an other.

\section{Love as Integral to Institutional Life}

Boltanski, through the event of the gift, seeks to make love into an exception to the social, an outside, a trace of the divine in our earthling doings. We would suggest that love as a being given, as a possession by another, including one unborn, is integral to the animation of all institutional life. The event of love is a manifestation of the movement that makes love operational, an endless movement towards another whom one cannot know, nor can one know who one will be in the movement. We have spent too much time thinking structures of locations and too little on the movement that inheres in doing that affords ways of being. Love, it is arguable, may be a general institutional operator (Friedland, 2013). What God does is clarify this givenness as love and the formation of will and desire it affords. Perhaps there is more sociological and phenomenological warrant for Diotima's injunction that we should understand love as a birthing in beauty whether it be babies or laws, new individual and collective bodies. If one thinks of love not monadically as an individual will to give, but as social and metaphysical forms of communion, of being with, afforded by different kinds of givenness, then one may be better able to account for the ways in which love repeatedly overflows the banks set for it in Boltanski’s text.

For Boltanski love and violence are modes of action that operate without equivalence, modes to which humans have recourse when equivalence fails, when either 
the tacit order of things falls apart or the explicit modes of justification fail. Boltanski's social theory suffers from a desirelessness, not only his separation of eros and agape, his identification of agape with the singular, desireless act of giving in the present, as opposed to the communion of persons, the historicity of having been given as the basis of a competence to give, or the givenness of the gift itself as a basis of being able to give and to receive in the cycle of either interested or generous exchange.

Modeling love on the gift, not the given, precludes the possibility of making love internal to institution, which can be understood as objectless givens which ground objectification and subjectification (Friedland, 2009). By cutting love from passion, he cognitivizes justice, unable to specify the deeper, more immanent, desire, both sensuous and metaphysical, that animates and sustains common goods. Love, like violence, is an institutional operator, inherent in modes of equivalence, not exterior to them.

\section{THE RETURN OF PRODUCTION}

\section{OJ and Love and Justice's Absence of Production of Value}

The central territory from which Boltanski moves outwards, both in $O J$ and in Love and Justice as Competences is that social zone which functions as a politicojuridical theater to judge the good, not the social organization to make it. The reality test is a convention for the observation of the quantity of a quality; it is not its production function. It was to exit from the path of economics combining factors of production as opposed to investments in forms and conventions that originally motivated Boltanski and 
Thévenot's project. This built on Thévenot's earlier work, seeking, not unlike his mentor Bourdieu did with the category of capital, to generalize the concept of investment beyond monetized capital and labor (Thévenot, 1984). Thévenot there argued it is through costly investment in forms - rules, codes, measurements - that allows for the establishment of equivalence between workers and commodities necessary to efficient coordination. ${ }^{30}$ It is through evaluation and qualification that coordination is effected; unequal distribution is a side-product of evaluation grounded in the equivalence necessary to the beneficent powers of coordination.

But it remains the case, although Thévenot's forms were meant to include inputoutput relations, that production of the good, of value, neither figures in $O J$ nor in Love and Justice. It is through tests, épreuves, that we constitute our commonality and the justness of the inequities to which evaluation inevitably gives rise and thus our capacity to a coordinate our actions. Tests are material practices of evaluation of persons, through which they are "assigned a legitimate qualification" (Boltanski and Thévenot, 2006: 127). "Tests of worth" are conventions that establish equivalence among people through things, according to which they have more or less worth with respect to a "common principle" (Boltanski and Thévenot, 2006: 141, 360). A test is a material procedure for qualifying people in relation to the good, a qualification that sustains the goodness of the good by establishing an order of worth among "beings," an "order of states [of worth] among which persons may be distributed" (Boltanski and Thévenot, 2006: 127). Such tests convert potentially violent conflicts over exclusion from value into conventions for adjudicating relative worth, converting the violence of dispossession into legitimate distributions of worth (Boltanski, 2012, pp. 54, 91-93; Bourguignon \& Chiapello, 2005; 
Dansou \& Langley, 2013).

Tests of worth are evaluations, not productions, of value. Tests of civic worth do not produce representation; they qualify a representative. Competitive transactions around a market price do not necessarily produce market value, they reveal it. Because it is justice that orients the project, value is only analyzed as it manifests itself within an order of worth. ${ }^{31}$ Production of value appears only in as much as it is delimited by the grammar necessary to justification. The production of the good is here conceptualized through an "investment formula" and a set of "sacrifices" which must be made in order to produce it. The "investment formula" characterizing each order is a double set of opportunity costs, both the privation of personal pleasures that have no relationship to that worth and the privatization of other collective goods that can only appear as personal pleasures, as private as opposed to collective goods (Boltanski and Thévenot, 2006: 142). These aspects of production are essential to justification of unequal worths in a democratic polity characterized by a "humanity" where all are equal and potentially capable of accessing that good. Sacrifices and investments are understood as opportunity costs, not as components of a production function.

Where the production of value, and its integral relation to distribution, was central to the classical Marxist analysis of the political-economic dynamics of capitalism, in which class struggle was part and parcel of both, capitalist production of value, that is, of capital, is, in fact, missing in $O J$. In their analytic partitioning of orders of worth identified in management manuals, Boltanski and Thévenot confine production to an industrial world separate from the market world of priced exchange, in which prices and private property express the desires of others. In Love and Justice, Boltanski glosses 
exploitation of labor as a "compromise between industrial and market arrangements," in which workers' exploitation is read through an industrial world of worth, establishing an equivalence of labor and social utility (Boltanski, 2012: 132). Capital, and capitalism, as such, disappears. By hiving off commodity circulation from capitalist production, this takes money as a neutral medium of exchange, here the Smithian medium by which to register, and hence evaluate, aggregate desire, as opposed to an institutional object, whose abstraction from use and thingness, its foundation as a symbol of value, both of what money cannot buy and what others cannot have, is critical to its productive operation as a source of capitalist expansion (Yuran, 2014).

The difficulties entailed by the analytic effacement of capitalist production as such, its decomposition into an aggregation of heterogeneous orders of worth, or powers (Susan, 2014), surfaced already in On Love and Justice. Boltanski argues there that reality tests in which objects are valorized, or qualified, and through which a person's worth is measured, are not deployed under conditions of fairness. "Equivalences are not involved in the situation. If there is no dispute, why engage in measuring" (Boltanski, 2012: 92-93). A regime of justice occurs when "things make demands," when people must speak for them, when they "demand that things change hands" (Boltanski, 2012: 70$71)$.

Critique thus typically emerges from a misalignment between the value of persons and the value of things, out of an "inappropriate attribution of things" to people whose value does not afford a proper "valorizatization" of those things. Critique, in other words, must derive from sub-optimal productivity, from members' understandings that an outward movement in the production frontier is possible, an element absent by design 
both here and in $O J$ (Arjaliès \& Friedland, 2015). ${ }^{32}$ There is no theory of the production of value, only the evaluation of worth. Although justice has a distributional aspect, Boltanski's formulation of critique here depends on the production of value, not just the evaluation of worth, as its basis. Without a theory of production, and without a way to interrelate production and distribution, not to mention the problematic identification of the relation of production and price characteristic of neo-classical economics, we will not be able to make our way towards a theory of critique.

New Spirit and Collection: An Attempt to Restore the Production of Value

It is in Boltanski's celebrated text with Eve Chiapello, The New Spirit of Capitalism, that capitalism made its analytic debut in his work, and Boltanski sought to claim his rightful place in the pantheon of critical theorists, as opposed to theorists of critique (Boltanski and Chiapello, 2007). Our treatment of this analytically rich and nuanced narrative will be cursory at best. This conjunctural political economy sought to link the massive political critiques carried by the movements of May, 1968, and the disruptions of production they entailed, to the transformation of the organization of capitalist production from Fordist hierarchical standardization to a "connexionist," project-based form of productive organization, on the one hand, and to the political pacification and the new justifications for, or "spirit" of capitalism, that had been put in place in France by the 1990's. Capitalism is defined by the authors as the "unlimited accumulation of capital by formally peaceful means" (p.5). The work centers on the capitalist productivity of forms of political critique, particularly new demands for 
"liberation" and "authenticity," as opposed to the more traditional critiques of "egoism" and "suffering," and their role in generating a "new spirit of capitalism" (Boltanski and Chiapello, 2007: 491). They associate the first two with the artistic critique carried by students, intellectuals and artists, and the second two with the social critique carried by the working class (Boltanski and Chiapello, 2007: 169).

It was the artistic critique that changed everything. French capitalism had responded to social critique through increased benefits and more security through legislation regulating industrial relations (Boltanski and Chiapello, 2007: 199). It was French employers' responses, their introduction of "new operational methods," to "the everyday oppression and sterilization of each person's creative, unique powers produced by industrial, bourgeois society," to demands for more autonomy, that both undercut the labor law" and afforded modes of self-realization eventuating in the "projective city" organized around temporary projects in which employees have the sense that they are both autonomous and creative, a "new, liberated, and even libertarian way of making profit" (Boltanski and Chiapello, 2007: 201, 171-172). Autonomy displaced security as the dominant value around which capitalism sought to both organize and justify itself, terms of enrollment that valorized worker adaptability and steadily eviscerated both the capacity for and efficacy of social critique. With "[t]he transformation of large collectives into flotillas of small structures, and the proliferation of different conditions for wageearners" tests of worth governing selection, remuneration and retention of workers based on a "unified space of calculation" were displaced by tests of strength (Boltanski and Chiapello, 2007: 313-314). 
The primary problematic in The New Spirit of Capitalism is the ways in which workers and consumers are induced to participate in and adhere to capitalism. The book tracks the ways in which these forms of critique were absorbed in changing modalities of testing, new forms of commodification of work, goods, and personal, disinterested, and particular forms of relations between persons and things, which vitiated and demobilized the sources of that critique. Capitalism's response to the critique of standardization and massification, for example, was to respond to the demands for authenticity into "products, allocated a price and hence exchangeable on a market, of goods and practices that in a different state of affairs remained outside the commodity sphere," to "humanize" services by commodifying interpersonal capacities, to convert use values "defined in a unique relationship to a user" into products with exchange value based on the "codification" and variation of their attributes which erodes the basis of individual authenticity, leading to cycles of infatuation and disappointment (Boltanski and Chiapello, 2007: 441, 443-447). While the result is a form of "complex domination," capitalism's incorporation of the artistic critique has, they suggest, "emptied the demands for liberation and authenticity of what gave them substance, and anchored them in people's everyday experience" (Boltanski \& Chiapello, 2007, p. 420; Susen, 2014, pp. 188-189).

In Love and Justice, fairness was distinguished from violence as modes of action, in which the former was organized around the tacit operation of objects and the latter was understood as a play of forces. The question is whether the tacit operation of objects derives from the lack of necessity of their being spoken for, as opposed to the necessity of their not being spoken, of the way their materiality depends upon, yet occludes, that which cannot be spoken. Is the tacit is what need not be spoken, because it is tacit, or 
cannot be spoken because it is occluded, an occlusion necessary to its efficacy? In the new spirit of capitalism, the silence of things is not fair at all. Tests are not tests of status, based on categorizations and general equivalences that ground justice; they are tests of strength, following a logic of displacement.

In this regime, tests may be defined as moments when beings, upon encountering resistance, seek to persevere by altering themselves - that is to say, displacing their energy in order to come to terms with other beings, in such a way as to profit from a difference, however minimal, which confers an advantage. The balance of forces, which is altered, is thus the outcome of the test (Boltanski \& Chiapello, 2007, p. 321, see also 315).

Under this form of capitalism, life is neither just, nor fair, and speaking has become extraordinarily difficult. People can barely speak for themselves. The situation, the open locus of justification in $O J$, has become an open-air prison.

Although the analysis identifies these changing operations of production as "new mechanisms of accumulation" (Boltanski and Chiapello, 2007: 420), this is not a study in capital formation, in the micro- or macro-economic dynamics of French capitalism. ${ }^{33}$ While the diffusion of flatter, flexible, temporally delimited project-based organization of production subsequent to the critique is documented, its actual relation to productivity and profitability, to capital formation and growth, is not an integral part of the authors' project. While the project, and the connections it affords, is a "temporary pocket of accumulation" that creates value, we actually know little about how value creation operates (Boltanski and Chiapello, 2007: 104). ${ }^{34}$ 
The mechanisms by which capitalist accumulation is accomplished in the new regime, specifically with regard to the commodification of authenticity -- things belonging to the past or associated with an exceptional individual, is broached in an essay, co-authored with Arnaud Esquerre, "La 'collection,' une forme neuve du capitalisme" (2014). This involves the creation of a new form of object, "the collection form," as opposed to the "standard form" of industrial capitalism. In the West, one out of four people maintain collections. It is not the attributes of the object, but the effects of conventions by which certain objects are "invested with their own value" in this “economy of wealth creation" (“enrichissement”) (Boltanski and Esquerre, 2014: 13). Boltanksi and Esquerre insist on the role of institutions to support the valuation processes associated with the form collection, in particular in the art collection. Nor does the love of the collector for their objects, which, they argue, points to psychoanalysis, not sociology, invest them with value (Boltanski and Esquerre, 2014: 23). Indeed, Boltanski argues, the singularities associated with love, must be bracketed in the analysis of this economy (Boltanski, 2014). In the collection form, la mise en valeur of the object is authenticated, its authenticity revealed, so to speak, through narrative and state categorization and collection which constitutes its difference (Boltanski and Esquerre, 2014: 15, 44). While the exchange of objects is essential to the collection form, valuation is anterior to price. It is this value that justifies the price (Boltanski and Esquerre, 2014: 22-23). Once again, the value of the objects collected has nothing to do with their production. If standard forms decrease in value over time; the value of collection forms increase. When objects acquire such value, when the relation of value and price is stabilized, which depends on their certification by independent agents who do not own 
them and their circulation, they become an asset, an "active form," and capital accumulation can take place. ${ }^{35}$ This mechanism of production, however, concerns only the goods which belong to the "collection form", i.e. goods produced in the past whose history is the basis of their value. Boltanski and Esquerre do not account for the production of value in the other forms of capitalism.

\section{The Missing Children}

Where did the children go? The production of life is missing, too. In $O J$, it wasn't just love that was absent: birth and babies were absent in Boltanski and Thévenot's domestic order of worth, the place you would most expect to find them. The domestic was rather conceptualized as chains of personal dependence that flow from generation, with no bodily fluids, no births, no sex differences, no desire. In On Critique Boltanski gives us love, but without babies, whose creation and social animation is likewise effected without discourse, with groans, cooing, laughter and tears, with enormous pleasure and pains, including the possibility of death hovering over it. It is uncanny how this accords with the original Christian supercession of God's promise to the Israelites, making human generation, and the divine commitment to fertility, irrelevant as a horizon of hope in which one awaited the rupture of human history, and in which one's ability to control one's desire, and sexual desire in particular, was an indication of superior faith and divine grace.

Whatever the source of his elision of life-making, Boltanski's de-corporealized understanding of divine love stands in stark contrast to the instituting moments of 
monotheism. These were all uterine dramas, divine conceptions: Sarah's aged birth of Isaac, one of Israel's founding patriarchs, Mary's (and her mother Elizabeth's) assisted fertilization of the anointed one, likewise evident in the birth of Huitzilopochtli, the Aztec founder whose mother was inseminated with divine feathers descended from the skies (Carrasco, 1999). Command over the life force is the prime property of divine sovereignty, the source of nationhood and of kings. The word of God, the letters of his very name, commands the making of life. That sovereignty is grounded in a claim to command life which will always exceed it, not as particularity, but as the ultimate reality upon which law and those who live within it depend. Sovereignty, like language, rests on the ability to command this reality, to make, to sustain, and hence - and derivatively, to take life.

Divine power over life-making cannot be separated from the constitution of sovereignty, contra Agamben, who, through the categories of "bare life" and homo sacer, centered his analysis on the divine taking of life outside the law, unhinged from its divine making, also beyond the law (Agamben, 1998). Boltanski, in contrast, identifies love with Christian agape, but again sets human and divine violence outside this metaphysical frame. In the Judeo-Christian tradition, in contrast, divine love and violence are twinned exceptions, outside of, yet interior to, revealed law. The exception is dual: the extra-legal and supra-sensible sources of mortality and fertility cannot be separated in the textual sources (Friedland, 2007). In the biblical sources it is the interior relation of divine love and violence that enables human creatures to survive, from the expulsion from the garden, to the saving of Noah, to God's decision to not annihilate the Israelites after their turning from Him to the worship of another god, to the crucifixion and resurrection of 
Christ. In each, it is divine love that furnishes the possibility of different forms of community - from the human species, to family, to the Israelite nation, to the Church. Life - both individual and collective -- is always an undeserved and unrepayable gift, unmerited because of willful rebelliousness, saved from divine violence by divine love. At each moment, divine powers are dual.

In his disapparition of babies, Boltanski in On Critique again follows in Arendt's footsteps who, although hallowing natality as affording us a capacity to begin as the basis of action as opposed to work or labor, made the actual birth of children irrelevant to action (Arendt, 1958). For Arendt natality, which leaves its traces in an inaccessible memory, is the locus of divinity within humans, to make new beginnings that appear to us "in the guise of a miracle" (Arendt, 1958: 178). Arendt, a Jew, secularized Christianity: We are all potential Christs, because like Christ, we have all been unprecedented children.

\section{Engendering the Fetus}

Boltanski would later take up the decision of birth, but not babies, in The Foetal Condition (2013). This is an analysis of a woman's decision to abort, a violation of the polity model's requirement of human dignity. The focus is not on birth, nor reproduction, but on "engendering," "the creation of new human beings who come to take their places in a world by already-present living beings and also by the memory of the dead" (Boltanski, 2013: 24, 33). These places are occupied by beings whose abstract singularity, their personhood, is originally grounded in kinship, the social order of 
filiation, who descends from whom. It is the threshold of beginning, not actual birth, that is at issue. Boltanski analyzes the institutional and phenomenological ways in which a fetus is given value, spoken for and thereby able to speak from and as a recognized place in society, an "authentic" fetus, as opposed to being denied that place, what he terms the "tumoral" fetus.

It is only in entry and non-entry to the parental project that a woman has the authority to decide to engender or abort. And it is here - and only here, it appears, in the parental project, that her love, understood as gratuitous and unrelated to the value of the object, is essential to that decision. In Boltanski's casting, a woman is torn between two wills, that of the flesh, which is "auto-affective," that is, an immanent and passive, present-oriented experience of plenitude or disquiet of "pregnant flesh," of the force of the growth within her, a place likened to the chora described in Plato's Timaeus, and the will to control, grounded in self-possession as a body that belongs to her, as an "I" in a relationship of a subject to objects necessary to inaugurate a future-oriented project (Boltanski, 2013: 199-203). It is through this "I" that the fetus is detached from the chora, as the body is dissociated from the flesh, becoming either "my baby" or just a thing (Boltanski, 2013: 212-213). It is love, Boltanski asserts, that governs the transition between the will of the flesh and the will to control, a love that he identifies with his earlier treatment of agape (Boltanski, 2013: 217-220). Love is without equivalence, beyond language, not dependent on the value of the object, gratuitous and grounded unlike passion -- in the intention of the "I."

Unlike Arendt, Boltanski does not dissociate natality from birth. But this mother love is at variance with the love of agape, as he described it, because it is both corporeal 
and social. It is grounded, through "auto-affectivity" in a sensuous body, a body with hormones that regulate plenitude and bonding that are the same ones regulating lactation, birthing and sexual orgasm, not to mention pair-bonding. This would suggest that Boltanski's earlier decision to purify love from the sexual, following Godelier (1996) such that sexual desire is conceptualized as a "permanent factor of violence," based upon force, might be a premature ejection (Boltanski, 2013: 31). And such love involves an "infinite" social relation with another, the elemental withness and withinness that a theorist like Sloteridjk has made the phenomenological ground of each "bell jar of purpose," contained within us at the same time we are contained within it (Slotedijk, 2011: 57). In this perspective the decision to birth is a decision for the biunity of humanness, for the production of humans. This love does not depend on the worth of the child to be, but on its value, on the value of life which Weber identified as the ground of all religions. What Boltanski's very sophisticated analysis of engenderment opens up is the prospect that love, not as a secularized Christian agape, but as something more fleshy, more passionate, might be not the outside of justice, but its inside. ${ }^{36}$

\section{THE RETURN OF INSTITUTION}

Value, Domination and Institution

Boltanski and Thévenot's polities are not Weberian institutional structures conjoining violence and legitimation. In their framework violence is excluded by fiat; legitimation supplanted by justification. "We seek to identify the forms of equivalence on 
which legitimate agreement is based by using classic political treatises, each of which presents, with reference to an equilibrium oriented toward justice, a universal principle intended to govern the polity." (Boltanski and Thévenot, 2006: 67) Their theoretical objects are not institutions at all. Conventions are rather linguistic and material "grammars" by which persons are bound in commonality in natural situations through tests of worth (Boltanski and Thévenot, 2006: 39, 346). They are virtual tools potentially available to individuals in any situation. "Rather than hypothesizing that value systems or cultures are tied to members of a single social group or a single institution, rather than presuming that values internalized in the form of ethical precepts or postures can be respected by a particular person in all circumstances of life, we hypothesized that a given person can refer to any and all measures of worth.” (Boltanski and Thévenot, 2006: 151). It is the plurality of the cités and their transposability that affords the capacity of critique (see also Boltanski, 2012: 29).

Boltanski's problematic has shifted from coordination to domination. After refusing to locate orders of worth at the institutional level in On Justification, Boltanski now argues On Critique, published two decades later, that we need institution to account for domination. The institutional level, he writes, "the order of instituted facts" was "ignored" in the "pragmatic paradigm" (Boltanski, 2011, p. 52). While the cities of worth approach specified both the actors' competence and the political grammar necessary to justify in the context of the assumption of a "common humanity" through an "investment formulae" that produced a "common good" in which all could participate, it cannot, he argues, explain the ways in which domination, persistent asymmetries in the state of worth, are sustained. Bourdieu's problematic of persistent group inequalities has called 
Boltanski back to attention. Domination is the truth of institution, located not in the control of resources, but in the specification of classes of non-existent beings.

Whereas earlier in The New Spirit of Capitalism, Boltanski and Chiapello had looked to "something like institutions" to restore legitimate tests (Boltanski and Chiapello, 2007: 470), institutions here have emerged as distinct sources of group domination. Persistent asymmetries inhere in test formats by which evaluations of worth are "tested." Boltanski points to the ways in which the "formats" or "types," used to qualify "beings," to establish their "worth," involve classifications that "distribute people between groups... and combine them with rules that exercise a constraint on access to goods and their use. They thereby play a major role in formation and stabilization of asymmetries" (Boltanski, 2011: 9).

Actors equipped with an array of metaphysical goods, with the grammatical logic of justification, and with conventions, or test formats, by which to establish the relative worth of beings, cannot by these means alone sustain a state of worth characterized by persistent inequalities and the entropy imposed by the world. Dispute over worth tends to reveal and release the uncertainty about the "whatness of the what is." The politics of evaluation threaten to descend into the deeper heat of ontological contest over what is good and what a good is, which entails uncertainty about and contests over what is, about the nature of the real. Such a descent shatters the premises of the pragmatic register, ordered neither according to plan, nor rules, but simply as "something to be done," "only aiming at the end of a sequence of action," oriented according to "reference points," internal disposition and external objects, through language which is lexical, not semantic. In a pragmatic register, one takes qualification of objects for granted; tokens serve as 
unproblematic representatives of types (Boltanski, 2011: 63, 65-66). The pragmatic register is what Boltanski previously called - in his multiplication of modes of action beyond justification -- "fairness," as opposed to "justice," a mode of action where equivalences are tacit, organized silently through the demands of things, "the equivalences that are tacitly enclosed in the silence of existing things," a re-working of the doxic order originally spelled out by Bourdieu (Boltanski, 2012: 67, 70). But with a major difference: What was once a mode of action characterized by "fairness" is now a pragmatic order which is not necessarily "fair" or "just" at all. There is no "implicit agreement...somehow ... immanent in the function of social life" (Boltanski, 2011: 61).

Justification itself is not homeostatic; it has transformative possibilities, as he and Chiapello demonstrated in The New Spirit of Capitalism. When critique releases the uncertainty immanent in social life; it can rise to and require a metapragmatic register that secures "the whatness of what is" (Boltanski, 2011: 56). That "whatness," he argues, cannot be generated through the iterative interaction between individuals armed with metaphysical and quasi-juridical competences to critique and justify, nor cannot it be secured by assuming that agreements over "the relative value of beings engaged in the dispute" can be resolved through "reality tests" (Boltanski, 2011: 27). Pragmatic sociology accords too much faith in the "common sense" of the actors, in their will to come to an agreement under conditions of dispute which unleash a radical uncertainty about the "whatness of the what is," an unease "latent" in every situation (Boltanski, 2011: 54-55, 57). "Thus uncertainty," Boltanski writes, "is both semantic and deontic in kind. It concerns the whatness of what is, and, inextricably, what matters, what has value, 
what is right to respect and look at twice." (Boltanski, 2011: 56). "Respect" inheres in the "second look" at an element as a token of a type, that we are doing "this."

Uncertainty has many sources. It derives not just from other symbolically constructed realities, what Boltanski and Thévenot used to call "worlds," but from the intrusion of what Boltanski now calls "the world," an immanence found in the "flux of life," particularly from the unqualified suffering and desire found there which potentially offer a ground for the formation of a new reality (Boltanski, 2011: 58, 113). Critique of any given reality that "hangs together," can draw on "events" of "the world" that "contradict its logic." Critique, he writes, "attains its most radical expressions in accommodating events or experiences extracted from the world" (Boltanski, 2011:59). The possibility of critique also derives from the fact that those authorized to speak for the world do so as embodied beings in a particular position within it making it impossible for any individual to authoritatively assert the "whatness of what is" without suspicion that he or she speaks from his point of view, expressing his interests and his authority. The operations of social practice cannot generate the "what is," particularly as this pertains to the creation of "non-existent beings," - like parties, organizations, or groups.

Nor can conventions of worth, he argues, secure a justified answer to the simple question: "why it is always the same people who pass all or most tests, whatever their nature, and, on the other hand, why it is always the same people who, confronted with all tests...prove mediocre... "(Boltanski, 2011:38). This, of course, was the prime object of concern in Bourdieu's critical sociology which stressed the ways in which structures of power were deposited in the disposition of actors who unconsciously replicated those structures without any manifest intention to do so. Boltanski does not use group powers 
to explain institution, but the reverse. It is the category of institution that allows him to explain "how actors small in number can establish enduring power over actors large in number, dominate them by exercising semantic control over the determination of what is and subject them to one form or other of exploitation." (Boltanski, 2011: 46). It is the link between contentious distributions and uncertain reality - both the formats of evaluation and the nature of value - that is key.

On Critique is not a complement to conventions of worth; it is its contradiction. Actors' willingness and capacity for agreement cannot account for the deontic force of test formats, their normative necessity. It cannot be derived from the iterative interaction of competent political actors who will settle on one or another universal good as a basis of evaluation. ${ }^{37}$ Agreement is neither likely, nor sufficient, to generate the normative force of test formats that generate skewed distributions of worth in which the same people always are found worthy or wanting. Reality can never be reduced to the world which both offers other forms of good, and reveals both the constructedness and the contingent applicability of reality tests (Boltanski, 2011: 117; see also Susen, 2014). Reality tests require institutional guarantees (Boltanski, 2011, p. 80; see also Thévenot, 2014, p. 247). The distributive dimension that was derivative of coordination via a common good in On Justification now becomes the analytic driver both of institution and critique. The structural inequities manifest in plural, but homologous, fields in the critical theory of Pierre Bourdieu are once again given pride of place. Once again it is group formation and "access to goods and their use" that is at the heart of domination (Boltanski, 2011: 9). Boltanski asserts, but does not specify, the co-implication of coordination and domination. The conditions for domination and critique are located in 
processes of classification, such that the efficacy of critique depends on the formation of a new collective to challenge and potentially displace the efficacy of qualifications through which groups with privileged access to resources are formed (Boltanski, 2011: 38-39). Because institution affords the worthiness of a group without groupness, critique depends on the formation of an alternative group, a "collective formulation of individual complaints," (Boltanski, 2011: 37). These require the development of "semantic instruments of identification and classification of social groups" (Boltanski, 2011: 38). We are back to the trinity of critique, class and classification.

Domination flows not out of situation nor structure, but out of institutional hegemony, over the fact that most of the time people do not challenge "test formats," which they take for granted as "stronger than they are" (Boltanski, 2011: 34). Reality tests work because the format of the good is rarely in question, and because its scarcity and inequitable distribution is represented as both real and necessarily so. Boltanski's solution to the problem of domination, to the asymmetries inherent in test formats, is to posit a necessarily "bodiless being", an institution, "a third party" whose primary function is semantic -- the determination and storage of definitions and the stabilization of reference, a bodiless being that declares the "whatness of what is" by defining a type and defending a particular situation as a token of that type (Boltanski, 2011:75, 79). Willingness and a capacity to agree are not enough. These materialized definitions and the formats through which qualification takes place must be backed up by the threat of violence, by coercive instruments of organization and administration, "means with which institutions must be equipped in order to act in the world of bodies" (Boltanski, 2011:79, 94). Following in Augustine's own trajectory who later in his career deployed the force 
of arms to enforce the one reality of Christ, semantic work, he writes, goes hand in hand with police work. Institutions are armed with rules and backed by sanctions. ${ }^{38}$ It is through this mechanism that one both says and confirms "what matters" (Boltanski, 2011:75). Violence is now internal to the operations of justice and to fairness. Domination haunts coordination, violence the common good.

\section{The Value of Institutions}

Value is central to the re-staging of the institutional in Luc Boltanski's On Critique (Boltanski, 2011). Value had been a common good to which actors made reference in conditions of dispute over the relative worth of beings. It was through the conduct of reality tests, through the deployment of the competence, mastery of a metaphysical grammar, and equipment, a constellation of objects - a dispositif - which identifies the situation in which a test and a grammar apply, and a common good has validity, that beings could be qualified across situations, their worth assessed, stripped of attributes irrelevant to the test, by which actors could resolve their disputes.

Value is central to the institutional function in Boltanski's framework. One cannot derive value from the iterative operation of tacit conventions. They "do not make it possible to generate a value and sustain the specifically normative character of the norm...with its deontic consequences" (2011:81). Institutions constitute "type situations," enabling a particular "state of affairs" to be qualified as a "token" of a "symbolic form." Value is central to qualification. The symbolic form is "logically 
arranged and laden with values" (Boltanski, 2011: 69). By associating objects with a type it joins them to other objects, "making it possible to invest them with a value."

But in what does value consist; where does it come from? The value of objects derives not from the nature of the object, but from its relation to a type, to a materialized semantics and a deontology that does not rely simply on the agreement of actors. Objects that matter are those that reference a type, "objects that matter...those which in our societies are taken charge of by the law or other forms of regulation not dependent on the state" (Boltanski, 2011: 70). Although deontic consequences, usages, flow from value (Boltanski, 2011:71), value is known through qualification. An object has value because it is taken as an instance of type, "related to its type" and "endowed with value" (Boltanski, 2011:70). Value derives from reference, from "respect" where an object is looked at twice, first indexically and second as a token of a type. "Respect," he writes, "therefore comes down to assigning relevance and hence a value." By being marked as a token of a type, it is "endowed with value" (Boltanski, 2011: 70). Value is neither productive, nor produced; it is semantically performed and coercively enforced. Value is valuation. Unlike $O J$ value is exogenous; it is not a substantive analytic category.

One can glean the problematic status of value in Boltanski's approach by looking at the thinker whom he references as a parallel to his own approach. Institutions establish value through their semantic function, by the logical definition of a "symbolic form" and the assignment of de-ontologies to objects that reference that form. In his linguistic understanding of institution Boltanski approvingly cites the semantic function of institutions in the philosophy of John Searle. "It is therefore first of all in its semantic functions that the institution must be considered (as does John Searle)" (Boltanski, 2011: 
75). For Searle institutions result from the conversion of collective intentionality into constitutive rules that assign agentive status functions -- "a collectively recognized status to which a function is attached" -- to ontologically objective "entities that cannot perform those functions without that imposition (Searle, 1995, p. 41). "Institutional facts" are agreed-upon cultural impositions on objective materiality, the same objectification of accord or imposition operative in On Critique. Intentionality is here a non-reducible collective capacity to represent objects and states of affairs to ourselves (Searle, 1995: 7). ${ }^{39}$ That constitution of institutional facts arrives through rules, not conventions, that assign status functions, an ontologically subjective fact, on an ontologically objective entity, in the form: $\mathrm{X}$ counts as $\mathrm{Y}$ in context $\mathrm{C}$. For example, paper bills $(\mathrm{X})$ issued by the Bureau of Engraving and Printing count as money (Y) in the United States $(\mathrm{C})($ Searle, 1995: 28). The objects to which status functions are collectively assigned need not have any inherent relation to the function that attaches to their status "by way of collective intentionality" (Searle, 1995:44).

For Searle institutional facts are collective representations of entities, continuous belief in which are necessary for them to function relative to "purposes, goals, and values" (Searle, 1995:19). Institutional facts are production functions that depend on collective belief, on the collective assignment of the status function. Functions are normative, not only in that they refer to an ontologically subjective value, but in that the X-term is "supposed to cause or otherwise result in Y." "Roughly speaking functions," he writes a decade later, "are causes that serve a purpose" (Searle, 2006, p. 17). Institutions afford powers constituted through the assignment of status functions, not as control over ontologically objective "brute facts." Institutions -- property, marriage, 
government -- are composed of nested status functions that generate enabling and constraining deontic powers, both authorizations and obligations. These iterated, interlocked status functions give the social a propositionally logical structure, which is a structure of power relations (Searle, 2006: 15).

Institutions are propositionally ordered power structures. Like Boltanski, Searle emphasizes the deontology of institutions, the assignment of function. The assignment of a status believed to enact a function derives from collective purposes exogenous to the institution, from collective intentionality, “doing, (wanting, believing, etc) something together..." (Searle 1995:24-25). Searle writes: "Where do the purposes come from? In any case it is not essential for the main argument . . that functions are observer relative, though I note it in passing" (Searle, 2006: 17). Institutions are structures of power whose purposes are analytically external to their constitution, located in extra-institutional collective intentionality. In an institutional logical approach, in contrast, it is not only the deontology of authority in that people believe in and agree to the assignment of $\mathrm{y}$ to $\mathrm{x}$, they believe in the value and the reality of the y (Friedland, 2016). The substantive nature of that value - as a good and a real - is co-constitutive of the de-ontologies of material practice. The ontology of objects and the de-ontology of practice cannot be so easily cleaved. Institutional objects - whether a border, ballot box, property or money - are not only objectifications of those values which entail specific forms of material practice in relation to them, but those values are only knowable through the actions these objects afford and demand. Boltanski's framework, characterized by the same externality of collective intentionality, the same exogeneity of purpose and value, cannot capture these co-implications. 


\section{Institution as Religion}

Institutions, absent in the pragmatic approach, are central to Boltanski's restaging of a critical sociology. The question is: What are they? As we shall see the question is really what is the this that is experienced as a who? Boltanski is acutely aware of the expansive social terrain to which the term can refer: a juridical real, an organization, or any form of social organization linking values and norms (Boltanski, 2011: 169). He, in fact, never defines them. He knows them by consciousness and consequences: phenomenologically by how people experience the exterior, perduring quality of a constructed social reality and functionally by the role they play in sustaining the reality of that real, in "stating the whatness of what is" (Boltanski, 2011: 75). As imagined beings institutions "solve" the "hermeneutic contradictions" of the suspicion of an interested point of view of the bodily spokesperson, of determining whether the spokesperson is really the "institution incarnée," and, through the confirmation of ritual that closes the gap between language and the specificity of the context of its enunciation (Boltanski, 2008, 2011, pp. 90-92). Institutions counter the fragility of the real; they support the agreements that ensue from tests of worth.

Institutions refer to non-existent entities which are both invoked and experienced as though they are disinterested, bodiless beings. An institution is a fictional being that captures people's experience of the source, the value and the exterior perdurance, and indeed potential eternity, of non-existent entities (Boltanski, 2011: 80-81). Instead of the Heideggerian "they," who are a figure for what everybody knows, the institution captures 
an imagined "he" or "she," a non-phenomenal being who establishes the real and its value and wants it to be respected, to follow the norms appropriate to it. Institution is the way in which we misrecognize symbolic violence and cover over physical violence. But an institution itself is not, he insists, an organization of authorized coordination or a coercive administrative apparatus (Boltanski, 2011: 79; Boltanski, 2008: 27). An institution, it seems, is a non-existent being imagined to guarantee the existence and authorize the value of non-existent entities. An institution is, in short, a god.

Institutions are members' categories, “mere fictions" (Boltanski, 2011:85). ${ }^{40}$ The institution is then, in Durkheimian terms, a collective representation. The issue is that Boltanski writes as though "institutions" exist as agentive entities, such as "the domination liable to be practiced by institutions" (Boltanski, 2011: 83). Durkheim interpreted totems as personifications of clan organization. What is the "it" that Boltanski conceptualizes as a "who"? Boltanski has personified the polities of his earlier work with Thévenot. Common goods, actor competences, and situated material conventions together constitute what Boltanski and Thévenot refer to as "polities" (Boltanski and Thévenot, 2006: 74-78). In $O J$, they had remarked on the way their analytic construction of orders of worth was a "more or less secularized theological order" (Boltanski and Thévenot, 2006: 127). In Love and Justice, Boltanski explicitly conceptualized the polities as "metaphysical beings" and people's competence to refer to the principles of equivalence grounding these polities as a "metaphysical capacity" (Boltanski, 2012: 43).

And five years before the publication of On Critique, Boltanski introduced institutions as bodiless divinities who appear in the very moment of production of live bodies. Centered on the decision to abort, in The Foetal Condition (2013) Boltanski 
wrote of orders of worth as "institutions," authorizing "fictional beings" (Boltanski, 2013: 62). Abortion stands at the uncertain transom between humanity by flesh and humanity by speech, an unrepresentable practical violation of humanness (Boltanski, 2013: 52). While women have the power to confirm the singular humanness of the body within their own, their authority to do so and the nature of the pre-confirmation is grounded in different institutions, bodiless agencies "external to persons": in divinity, the kin group, the industrial nation-state, and - extending the connectionist and network logic of contemporary capitalism analyzed in The New Spirit of Capitalism - the project polity (Boltanski, 2013: 67). These institutions are sources of pre-confirmation and specify "the way the typical relation between sexual intercourse and engendering is orchestrated." It is institutions, not parents, who ground the authority to "create a new human being and deposit it in the world (Boltanski, 2013: 63).

In the first divine order, "every being who comes in the flesh is viewed as already preconfirmed in its humanity as a child of God, made in God's image, and thus called to salvation" (Boltanski, 2013: 67). In the second domestic order, a fetus can be confirmed by speech into a singular place in recognized lines of filiation through the legitimacy of its procreation through marriage. In the third, it is the usefulness of the beings to the nation state - both in their quantity and quality - that governs engendering. In the fourth, and final, project form of understanding, it is the "parental project" that "presided over its conception," a supra-individual contract, an "agreement through which a man and a woman bond together with the intention of creating a child," an agreement that need not have any relation to marriage or even cohabitation, only to the project of parenting (Boltanski, 2013: 94). 
It is striking that in On Critique Boltanski relies on a religious figuration, an institution as a bodiless being equipped with a "pure will," to explain domination through its semantic function (Boltanski, 2011:66, 96). Given the anti-institutionalism and the situationalism of his previous work, one might imagine that Boltanski, in order to understand persistent asymmetries immanent in test formats, might have turned to the constellations of objects so central to the conduct of "reality tests" (Boltanski, 2011: 28). ${ }^{41}$ That way is blocked because of the subordinate role of objects in this approach, in which "repertoires of objects whose comparison and internal coherent alignment outlines spheres of pertinence" (Boltanski, 2011:28; Arjaliès and Friedland, 2015). Domination is primordially semantic (Boltanski, 2011: 9). Objects -- institutionally qualified, imprinted, classified, infused -- are subordinate to signs. "To institutions thus fall all the tasks that consist in fixing reference, especially when it bears on objects whose value is important and whose predicates must be stabilized by definitions" (Boltanski, 2011:76). Objects here do not produce value, but function primarily as signage for sites in which evaluation ought to take place, classified as tokens of types. Instead of turning to what ANT would refer to as mediators which have effects, Boltanski eschews the enabling and constraining role of constellations of objects themselves, "material as opposed to social compacts" to which Latour pointed as the basis for explaining the perdurance of "asymmetries" (Latour, 2005: 70). It is the sign, not the thing, that is hegemonic. It is semantics, to which practical de-ontologies are attached, that are the "domain par excellence of institutions" (Boltanski, 2011: 92). Institutional truth tests typologically and linguistically confirm the relationship between forms and states of affairs by reduplicating codes and formulae; reality tests materially assess the powers of beings 
through their acts based on the good whose worth is being evaluated (Boltanski, 2011: 104-106).

Disputes over evaluation have an inherent tendency to become contests, even violent ones, over the nature of the real, over truth and value. Their containment requires a metapragmatic register that only an institution can provide. Boltanski imagines the confirmatory "truth tests" which secure this register as religious rituals in which the difference between symbolically constructed reality and the world is effaced (Boltanski, 2011: 89). Boltanski understands the institutional moment through the repetitive, selfreferential and symbolic coherence of choreographed practice of religious ritual as a way to confirm the reality and value of the real from the critiques emanating from the "suffering and desire" that issues from the world (Boltanski, 2011: 90, 99, 101). It is not the moral-material grammar of political justification, but the coercive machinery of religious ritualization as a semantic drama, where language and practice coincide, to which Boltanski turns to model institution. Religious ritual is his model of what he calls the "truth test," exhibitions of "what creates value" (Boltanski, 2011: 106).

Given religion's exclusion in $O J$, its use as a model for the metapragmatic is a little startling. In $O J$, ritual had been explicitly rejected as a way of framing of tests of worth; the "plenitude" of "self-evident situations" was rather grounded in the "mutual substantiation" of each "being" being in its "proper place" (Boltanski and Thévenot, 2006: 132). Pragmatic regionalized inter-objectivities now depend on a relationship to a higher non-existent subject, not unlike the way Durkheim argued the totem contributed to the formation of clans. Now he writes that it is in religious rites that "the presence of the bodiless being is revealed...by the constraint that the sequence of the ritual imposes on 
all participants." It is through the common choreography of religious rite that one "realize[s]" "a virtual, yet material, analogue to the bodiless being...This kind of system has thus constituted, as it were, a stock or board of paradigmatic practice that other functionalities drew on every time they had to rely on reference to bodiless beings." (Boltanski, 2011:89).

All institutional practice is religious; we live with gods because we live in symbolically constructed realities. God talk is the machine-language of institution. Religion, the domain that could not be a polity in $O J$, now grounds every polity. "[R]eality," he writes, "constructed under the power of institutions, is positioned as a continuation of ritual...[I]it constitutes an attempt, necessarily doomed to failure, to push ritualization beyond the limits" (Boltanski, 2011:91). And it is through rite that one renounces one's personal reflexivity and rather experiences the "reflexivity of the system as a whole and its capacity to make manifest what is" (Boltanski, 2011:102). It is in this moment that one experiences something interpreted as "emotion," an "experience of a kind of plenitude of meaning...in assuagement of the unease about the existence of what is and what has value - of what one is attached to, in the affective sense of the word." It is institutional rite that reveals the good, not productive practice that makes the good, that one is able to love that there is a common reality, one in which there are no gaps with the world, where semantics and practical norms have been sutured together. In the institutional moment, we are the world. At this moment, the value of reality is the reality of value.

The bodiless "beings" who compose Boltanski's institutions are gods, suprasensible, willful beings who intervene in our world and in our hearts. Institutions are 
collective representations, the languages and material practices of ritual self-referential and tautological. What then do they re-present? The gods can never be present. The "it" which becomes this institutional "who" must be the common good or value, the absolute, in whose name the formats are fixed, the classes arrayed (Boltanski, 2011: 95, 97). Institutions are collective representations of common goods which sustain the interests of dominant groups. It is their ability to appear as bodiless beings that covers and legitimates the violence and the domination inherent in institution, their enforcement and administration of an arbitrary deontology, their attempt to subordinate the world, the specificities of context, the inevitable impurity of situation, to its reality. Only institutions can secure types such that people act as though they were "eternal entities" (Boltanski, 2011:75). The gods themselves, the givens, values or substances, that ground the rituals, their productivity as regimes with practical effects, able not only to confer value as a token of a type, but to create value, to sustain human projects, and humanity itself, are not within this institutional analysis. This is a performative ritualism without the divinities through which it would make sense and be organized in particular ways, ways that have a non-arbitrary relationship to their nature.

By turning to ritual as the institutional moment, Boltanski has forwarded an idolatrous treatment of ritual practices which are impractical without the god which exceeds them, the truth of the value, or divine substance, upon which they are founded, and unbelievable without the practices through which they are produced. For Boltanski religious rite is not the pragmatic register, where language is indexical, action a set of linked routines through which one moves indifferent to practical variation, and practical consequences are paramount, that sustains the "whatness of the what is," but the 
metapragmatic where language is semantic, where the relation between type and token is secured, where practical variation is excluded, and practical consequences are irrelevant. It is the how of the rite, not its effects, that generate confirmation of what is. The institutional moment operates not through potentially contentious reality tests, but through "confirmatory" "truth tests."

Religious rites do not have contexts; they suture reality and world. By making institution the exterior guarantee of evaluation and by rendering institution tautological, Boltanski repeats a version of the Weberian duality of instrumental and value rationality. Although Boltanski does not subjectivize value rationality, maintaining the link between value and ritual practice, he segregates instrumental and value rationality, the pragmatic and the metapragmatic, through exteriority, thereby locating the institutional in rite without consequences and the pragmatic in consequential practices without rite

\section{THE HIGHLIGHT OF THE GODS?}

Love, violence, religion, production, institution: In his theoretical and explanatory works Boltanski sought to recuperate each of these elements absent in OJ (cf. Table 1 for a tentative summary of our analysis). He specify or neutralize the theoretical opportunity costs, and thereby,to restore a kinship with conventional understandings of critical sociology. Although we have moved from grammars of justification to hegemonic semantics, from agreement to violence, from coordination to domination, the "religious" question of value, its production or enactment, the emotions through which it is sustained and revealed, the love and the violence of which it is composed and composes, is as 
vexed as ever. Boltanski has prepared a landing pad for the gods to appear once again on our earth, for thinkers to re-appropriate their powers to understand and to clarify human projects. It is time to imagine that we, too, are loved by the gods - as givens, that they give us to ourselves and can likewise destroy us and each other, that there is sometimes an incalculable immanent in calculation, that there is love and violence within justice and fairness, that creation and production must be thought together. If we are to give each other a new world, we must understand more clearly the multiple supra-sensible ways in which this one is given, there, right before and in our eyes. 
Table 1: A Reader's Matrix for Our Analysis of Luc Boltanski's Texts

\begin{tabular}{|c|c|c|c|c|c|c|}
\hline & Love & Violence & Religion & Production & Institution & Emotions \\
\hline $\begin{array}{l}\text { On Justification: } \\
\text { Economies of Worth } \\
(1991 / 2006)\end{array}$ & - & $\begin{array}{l}\text { An instance of } \\
\text { relativization, } \\
\text { the failure of } \\
\text { justification and } \\
\text { a descent into } \\
\text { relativization }\end{array}$ & $\begin{array}{l}\text { A non-divine } \\
\text { model for } \\
\text { creation found } \\
\text { in the cité of } \\
\text { Inspiration }\end{array}$ & $\begin{array}{l}\text { Located as a material } \\
\text { productivity in the } \\
\text { industrial cité }\end{array}$ & $\begin{array}{l}\text { A "being"-like } \\
\text { persons, tools and } \\
\text { names formatting a } \\
\text { natural situation }\end{array}$ & $\begin{array}{l}\text { Evidence in the cité of } \\
\text { inspiration }\end{array}$ \\
\hline $\begin{array}{l}\text { Love and Justice as } \\
\text { Competences } \\
(\mathbf{1 9 9 0 / 2 0 1 2 )}\end{array}$ & $\begin{array}{c}\text { A-social } \\
\text { competence that } \\
\text { makes it an } \\
\text { impossible mode } \\
\text { of justice } \\
\end{array}$ & $\begin{array}{l}\text { Mode of action } \\
\text { through force }\end{array}$ & $\begin{array}{l}\text { Christian agape } \\
\text { the } \\
\text { model/source of } \\
\text { love }\end{array}$ & $\begin{array}{l}\text { Productivity the ground } \\
\text { for disqualification in } \\
\text { orders of worth } \\
\text { (not studied here) }\end{array}$ & $\begin{array}{l}\text { Organizations through } \\
\text { which persons } \\
\text { associated (by } \\
\text { belonging to the same } \\
\text { institution) }\end{array}$ & $\begin{array}{l}\text { At the boundaries of modes } \\
\text { of action }\end{array}$ \\
\hline $\begin{array}{l}\text { The New Spirit of } \\
\text { Capitalism, with E. } \\
\text { Chiapello (1999/2000) }\end{array}$ & - & $\begin{array}{l}\text { Domination of } \\
\text { the "grands" } \\
\text { over the "petits" } \\
\text { through tests of } \\
\text { strength }\end{array}$ & - & $\begin{array}{l}\text { Changing organization } \\
\text { of production as } \\
\text { mechanisms of } \\
\text { accumulation }\end{array}$ & $\begin{array}{l}\text { Sources of group } \\
\text { domination }\end{array}$ & $\begin{array}{l}\text { Among the sources of the } \\
\text { problems of capitalism }\end{array}$ \\
\hline $\begin{array}{c}\text { The Foetal Condition: } \\
\text { A Sociology of } \\
\text { Engendering and } \\
\text { Abortion }(2004 / 2013)\end{array}$ & $\begin{array}{l}\text { Agape as the } \\
\text { source of the } \\
\text { decision to birth }\end{array}$ & $\begin{array}{l}\text { Abortion as non- } \\
\text { engenderment }\end{array}$ & An institution & - & Bases of engenderment & $\begin{array}{l}\text { "Emotional project" or the } \\
\text { relationship between the } \\
\text { women and her partner } \\
\text { and/or her foetus. }\end{array}$ \\
\hline $\begin{array}{l}\text { On Critique: A } \\
\text { Sociology of } \\
\text { Emancipation } \\
(2009 / 2011)\end{array}$ & $\begin{array}{l}\text { At the boundary } \\
\text { of practice } \\
\text { A competence } \\
\text { exterior to justice }\end{array}$ & $\begin{array}{l}\text { Internalized as } \\
\text { "police," } \\
\text { immanent as } \\
\text { symbolic } \\
\text { violence to the } \\
\text { semantic register } \\
\text { of institutions } \\
\end{array}$ & $\begin{array}{l}\text { The model } \\
\text { institution }\end{array}$ & $\begin{array}{l}\text { Modes of production } \\
\text { linked to the Marxist } \\
\text { view (who owns the } \\
\text { means of production) }\end{array}$ & $\begin{array}{l}\text { A bodiless being that } \\
\text { grounds the "whatness } \\
\text { of what is" }\end{array}$ & $\begin{array}{l}\text { The basis of existential tests } \\
\text { And the experience of } \\
\text { "plenitude" in truth tests }\end{array}$ \\
\hline $\begin{array}{l}\text { Une Forme Neuve du } \\
\text { Capitalisme - La Mise } \\
\text { en Valeur Economique } \\
\text { du Passé et ses Effets } \\
\text { (2014) with A. Esquerre }\end{array}$ & $\begin{array}{l}\text { Psychoanalytic } \\
\text { topics that } \\
\text { should remain } \\
\text { outside } \\
\text { sociology }\end{array}$ & - & - & $\begin{array}{l}\text { Individuals' investment } \\
\text { of value in objects }\end{array}$ & $\begin{array}{l}\text { Support the valuation } \\
\text { processes }\end{array}$ & $\begin{array}{l}\text { Psychoanalytic topic that } \\
\text { should remain outside } \\
\text { sociology }\end{array}$ \\
\hline
\end{tabular}




\section{ACKOWLEDGMENTS}

We thank Eve Chiapello, Thibault Daudigeos, Damon Golsorki, John Levi Martin, Laurent Thévenot and David Stark, for their helpful comments on earlier versions of this paper. We also also thank Editors Charlotte Cloutier, Jean-Pascal Gond, Bernard Leca and two anonymous reviewers for their extremely helpful and supportive feedback throughout the review process.

\section{REFERENCES}

Agamben, G. (1998). Homo sacer: Sovereign power and bare life. Stanford University Press.

Alexander, J. C. (2006). The civil sphere. USA: Oxford University Press.

Arendt, H. (1958). The human condition. University of Chicago Press.

Arendt, H. (1996). Love and Saint Augustine. University of Chicago Press.

Arjaliès, D.-L., \& Friedland, R. (2015). The Object of Institutional Logics. Unpublished Working Paper.

Augustine. (2009). The Confessions. New York: Oxford University Press.

Boltanski, L. (1990). L'amour et la justice comme compétences. Paris, Métailié.

Boltanski, L. (2004). La Condition foetale. Une sociologie de l'avortement et de l'engendrement. Paris: Gallimard.

Boltanski, L. (2008). Institutions et critique sociale. Une approche pragmatique de la domination. Tracés. Revue de Sciences Humaines, (8), 17-43.

Boltanski, L. (2009). De la critique: précis de sociologie de l'émancipation. Editions Gallimard.

Boltanski, L. (2011). On critique: A sociology of emancipation. Polity.

Boltanski, L. (2012). Love and justice as competences. Polity.

Boltanski, L. (2013). The foetal condition: a sociology of engendering and abortion. John Wiley \& Sons.

Boltanski, L., \& Chiapello, E. (1999). Le nouvel esprit du capitalisme. Paris, Gallimard.

Boltanski, L., \& Chiapello, E. (2007). The new spirit of capitalism. Verso.

Boltanski, L., \& Esquerre, A. (2014). La “collection", une forme neuve du capitalisme: la mise en valeur économique du passé et ses effets. Les Temps Modernes, 679, 572.

Boltanski, L., \& Thévenot, L. (1991). De la justification. Les économies de la grandeur. Gallimard.

Boltanski, L., \& Thévenot, L. (1999). The Sociology of Critical Capacity. European Journal of Social Theory, 2, 359-377.

Boltanski, L., \& Thévenot, L. (2006). On Justification: Economies of Worth. Princeton, NJ: Princeton University Press.

Bourdieu, P. (1984). Distinction: A social critique of the judgement of taste. Harvard University Press.

Bourdieu, P. (1998). Practical reason: On the theory of action. Stanford University Press.

Bourdieu, P. (2001). Masculine domination. Stanford University Press. 
Bourguignon, A., \& Chiapello, E. (2005). The role of criticism in the dynamics of performance evaluation systems. Critical Perspectives on Accounting, 16(6), $665-700$.

Carrasco, D. (1999). City of sacrifice: The Aztec empire and the role of violence in civilization. Beacon Press.

Chateauraynaud, F. (1991). La faute professionnelle: une sociologie des conflits de responsabilité. Editions Métailié.

Chiapello, E. (1998). Artistes vs. Managers. Le Management Culturel Face à la Critique Artiste. Paris: Métailié.

Chiapello, E., \& Boltanski, L. (2001). Comment interpréter les changements du capitalisme - réponses à quelques critiques. Sociologie Du Travail, 43, pp-409.

Dansou, K., \& Langley, A. (2013). Institutional work and the notion of test. $M @ N @$ Gement, 15(5), 503-527.

Derrida, J. (1998). Faith and Knowledge: the Two Sources of "Religion" at the Limits of Reason Alone. In J. Derrida \& G. Vattimo (Eds.), Religion (pp. 1-78). Stanford: Stanford University Press.

Friedland, R. (Forthcoming). Moving Institutional Logics Forward: Emotion and Meaningful Material Practice. Organization Studies.

Friedland, R. (2009). Institution, Practice and Ontology: Towards A Religious Sociology. In R. E. Meyer, K. Sahlin, M. J. Ventresca, \& P. Walgenbach (Eds.), Institutions and Ideology. Emerald.

Friedland, R. (2013). God, Love and Other Good Reasons for Practice: Thinking Through Institutional Logics. Research in the Sociology of Organizations, 39, 25-50.

Friedland, R. (2014). Divine Institution: Max Weber's Value Spheres and Institutional Theory. Research in the Sociology of Organizations, 41, 217-258.

Friedland, R. (2016). The Value of Institutional Logics. In G. Kruecken, R. Mazza, P. Meyer, \& P. Walgenbach (Eds.), Topics and Issues from European Research. Cheltenahm: UK: Edward Elgar Publishing.

Friedland, R., Mohr, J. W., \& Roose, H. (2016). The Institutional Logics of Love: The Order of Passion in an Intimate Field. Presented at the American Sociological Association Annual Meeting.

Gadrey, J., \& Hatchuel, A. (2001). Le nouvel esprit du capitalisme. Sociologie Du Travail, 389-421.

Godelier, M. (1996). Meurtre du père-sacrifice de la sexualité: approches anthropologiques et psychanalytiques. Arcanes.

Holdrege, B. A. (1995). Veda and Torah: Transcending the textuality of scripture. State University of New York Press.

Latour, B. (2005). Reassembling the social: An introduction to actor-network-theory. Oxford university press.

Lemieux, C. (2014). The Moral Idealism of Ordinary People as a Sociological Challenge: Reflections on the French Reception of Luc Boltanski and Laurent Thévenot's On Justification, In S. Susen \& B. S. Turner (Eds.), Spirit of Luc Boltanski: Essays on the "Pragmatic Sociology of Critique" (pp.153-170). London: Anthem,.

Leys, R. (2011). The turn to affect: A critique. Critical Inquiry, 37(3), 434-472.

Luhmann, N. (2010). Love: A sketch. Polity. 
Maguire, M. W. (2006). The conversion of imagination: From Pascal through Rousseau to Tocqueville (Vol. 151). Harvard University Press.

Marion, J.-L. (2005). The reason of the gift. In Giveness and God: Questions of Jean-Luc Marion (pp. 101-134). New York: Fordham University Press.

Marion, J.-L. (2011). The reason of the gift. University of Virginia Press.

Marion, J.-L. (2012). God Without Being. Chicago: University of Chicago Press.

Martin, J. L. (2011). The Explanation of Social Action. USA: Oxford University Press.

Massumi, B. (2002). Parables for the virtual: Movement, affect, sensation. Duke University Press.

Pagels, E. H. (1989). Adam, Eve, and the Serpent: Sex and Politics in Early Christianity. Vintage.

Pasquier, V., Daudigeos, T., Jaumier, S., \& Edwards, T. (2015). Grasping elusive domination in connectionist organizations. Paper Presented at the 4th European Theory Development Workshop.

Plato. (1999). Plato: the symposium. Penguin Books.

Rousseau, J.-J. (1761). Julie, ou La Nouvelle Héloïse. Euvres Complètes, 2, 1-745.

Rousseau, J.-J. (1762a). Du contrat social ou Principes du droit politique. Halbwachs (Éd.), Aubier-Montaigne.

Rousseau, J.-J. (1762b). Émile, ou De l'éducation (Vol. 2).

Searle, J. R. (1995). The construction of social reality. Simon and Schuster.

Searle, J. R. (2006). Social ontology Some basic principles. Anthropological Theory, $6(1), 12-29$.

Silber, I. F. (2014). Luc Boltanski and the Gift: Beyond Love, beyond Suspicion...? Reflections on Luc Boltanski's “On Critique”. In S. Susen \& B. S. Turner (Eds.), The Spirit of Luc Boltanski (pp. 173-209). London: Anthem.

Smith, P. (2015). Some Implications of "On Justification” for Social Theory and Cultural Sociology. Department of Sociology, University, Unpublished.

Susen, S. (2014). Is There Such a Thing as a "Pragmatic Sociology of Critique"? In S. Susen \& B. S. Turner (Eds.), Spirit of Luc Boltanski: Essays on the "Pragmatic Sociology of Critique” (pp. 173-210). London: Anthem.

Thévenot, L. (1984). Rules and implements: investment in forms. Social Science Information, 23(1), 1-45.

Thévenot, L. (2007). The plurality of cognitive formats and engagements moving between the familiar and the public. European Journal of Social Theory, 10(3), 409-423.

Thévenot, L. (2014). Enlarging conceptions of testing moments and critical theory: Economies of Worth, On Critique, and Sociology of Engagements. In S. Susen \& B. S. Turner (Eds.) (pp. 245-261). London: Anthem.

Todd, C. (2014). Emotion and value. Philosophy Compass, 9(10), 702-712.

Vaisey, S. (2009). Motivation and justification: a dual-process model of culture in action. American Journal of Sociology, 114(6), 1675-1715.

Weber, M. (1958a). Religious rejections of the world and their directions. In H. Gerth \& C. Wright (Eds.), From Max Weber: essays in sociology (Vol. 2, pp. 323-362). New York: Oxford University Press.

Weber, M. (1958b). The Protestant Ethic and the Spirit of Capitalism. New York: Scribners. 
Wolfson, E. (2015). Givenness and the Disappearance of the Gift: Ethics and the Inivisible in Marion's Christocentric Phenomenology. In C. Welz (Ed.), Ethics of In-Visibility: Imago Dei, Memory, and Human Dignity in Jewish and Christian Thought (pp. 169-191). Tubingen: Mohr Siebeck.

Yuran, N. (2014). What money wants: an economy of desire. Stanford University Press. 


\section{NOTES}

${ }^{1}$ It was Thévenot's essay on investment in form, centering on forms, rather than positions or capitals, that led to the break with Bourdieu. (Thévenot, 2014, p. 247)

2 Jeffrey Alexander, in his positing of a civil sphere whose codes are the grounds for justification, makes a related kind of claim (Alexander, 2006).

${ }^{3}$ The "beings" forming a "coherent and self-sufficient world" include "persons, institutions, tools, machines, rule-governed arrangements, methods of payment, acronyms and names, and so forth..." (Boltanski and Thévenot, 2006: 40-41).

${ }^{4}$ Thévenot will later point to the ways in which a materially formatted environment "offers a pledge (gage) that guarantees the human being's valued capacity" (Thévenot, 2014: 248).

${ }^{5}$ Phil Smith, in an unpublished review of On Justification argues that their approach "allows them to record the logic of justifications but not their spirit.... The cultural sociology literature takes a very different approach, one that suggests passionate emotions, symbolic logics and obstinate value commitments are pivotal to decision making and legitimacy claims" (Smith, 2015).

${ }^{6}$ Thévenot would later vertically differentiate modes of engagement based on "cognitive forms" beyond the justice of worth to less public goods: the individual will of a plan and the ease of familiarity, pointing to the marked ways in which one coordinates not only with others, but with oneself, ways that depend neither on semantics nor institution (Thévenot, 2007, 2014, p. 249).

${ }^{7}$ Boltanski writes: "From this standpoint, it is precisely because they are parties to the affair that concerns them intimately that actors cannot grasp the truth of their actions. Bound to the social world by interests they tend either to dissimulate the truth when it is contrary to their interests or...to conceal from themselves the truth of their acts and their positions." (Boltanski, 2012:19).

${ }^{8}$ Pasquier, Daudigeos, Jaumier and Edwards (2015) have sought to specify the forms of power and resistance associated with each mode of action. Notably, they identify love - here care without calculation - as a basis of critique and emancipation, as well as in the regime of the "good company," in which employees relate to the firm without calculation and with low levels of reflexivity.

${ }^{9}$ This is far from a critical Marxist understanding of the coercion historically and actually embedded in the formation and operation of capital's objective equivalences.

${ }^{10}$ As Vaisey has pointed out it is difficult to parse the conditions under which cultural value is justification and/or motivation, given that individual accounts of morality are sketchy and contradictory, and often have little relationship with what people actually do (Vaisey, 2009).

${ }^{11}$ Although asserting that the refusal of judgment internal to agape depends on Christian revelation, on a new relation between humans and God, "the expectation of parousia, or the second coming, does not modify the modalities of the relationships among human beings that it prescribes for the present" (Boltanski, 2012: 114).

${ }^{12}$ Agape can be secularized in either case. This is not say that Boltanski is a Catholic sociologist any more than one would say that those, like Thomas Hobbes, who espoused a sovereign who must stand outside the law is a late medieval Christian nominalist, a theology which argues that the absolute power of God cannot be constrained by his revealed law.

${ }^{13}$ Hebrew for justice and charity.

${ }^{14}$ God's promise to the first patriarch coincides with a name change -- Abram to Abraham, Sarai to Sarah - the addition of the same letter, the hey, the double letter in God's name, into the name of both husband and wife (Genesis 17:5, 15). God's word, particularly the letters of his very name, inseminates as it authorizes. As Barbara Holredge points out, the twenty-two letters of the Hebrew alphabet constitute the "very substance of the Godhead." (Holredge, 1996: 214). 
${ }^{15}$ The theory of love certainly matters to erotic passion. In Friedland and his collaborators work on erotic love among American college students, controlling for a host of attributes, including sexual acts, those who self-consciously believe in romantic love, who dismiss the notion that it is a nostrum that brainwashes women, are much more likely to experience feelings of passionate love in their last intimate encounter, including feeling their bodies respond and wanting their partners to know all about them (Friedland, Mohr, \& Roose, 2016).

16 "And then there is the question of your inner feelings. Have they not been given to you? Doesn't reading novels help you know how to love?" (Latour, 2005, p. 209).

${ }^{17}$ As Silber notes, pure agape has a "sociological impossibility" and that Boltanski's agape is "non-amenable to sociological analysis" (Silber, 2014, p. 488).

${ }^{18}$ This autistic Christian understanding of love is at odds with Boltanski's own reading of Marx's unalienated labor where people's activities are forms of self-giving, of a need to create, to externally objectivize so that one is publicly available for others (Boltanski, 2012: 131-138). For Heidegger, not unlike Marx, giving is a possibility of being not defined by things, by one's understanding of oneself and others as things, as Enframing. For Heidegger giving is an intersubjective modality of care in which one "leaps ahead" affording the other his potentiality for being as opposed to "leaping in" and disburdening him of it. For Bataille giving is in the nature of the cosmos, like the sun, a limitless expenditure perversely mimed by states in wars and spectacles. Each of these figure giving as a social, interactional order, animations of social life.

${ }^{19}$ Thévenot ties the "marks" of material singularity to the regime of familiarity, which never moves into language when one "opens one's eyes": "there is no recourse to language, interpretation or reflexivity...There is no critique, or criticism either. And yet, there is a selfdistancing from the mark." (Thévenot, 2014: 250).

${ }^{20}$ This singularity also haunts case law.

${ }^{21}$ Derrida likewise de-corporealizes the structure of religious experience immanent to sociality while using sexual bodily forms - whether womb or phallus by which to figure it.

${ }^{22}$ Pope John Paul II, "Man Becomes the Image of God by Communion of Persons," General Audience of November 14, 1979, "Man and Woman: A Mutual Gift for Each Other," Audience of February 6, 1980, http://www.ewtn.com/library/PAPALDOC/jp2tb9.htm

${ }^{23}$ En effet, une chose peut sans doute, au même titre qu'une personne, être considérée dans ce qu'elle a de singulier et faire alors l'objet d'un intense investissement affectif, voire d'une passion exclusive - comme le revendiquent souvent les collectionneurs qui, comme nous le verrons, jouent un rôle important dans les économies de l'enrichissement, en mettant l'accent sur le caractère irrationnel de leur pratique, confinant à la manie. Mais cette façon de concevoir la relation entre des êtres humains et des objets tend alors à se soustraire à la sociologie au profit des disciplines qui font référence à des actions inconscientes, comme c'est le cas de la psychanalyse. (Boltanski and Esquerre, 2014: 23)

${ }^{24}$ Boltanski and Chiapello's enumeration of "inspired manifestations," are - with one exception identical to the artistic critique: "holiness, creativity, artistic sense, authenticity" (Boltanski and Chiapello, 2007: 23).

25 "One important issue," Todd notes, "is the general challenge posed in accommodating affect and intentionality in the same unitary mental state." (Todd, 2014, p. 704).

${ }^{26}$ Because of the centrality of a represented value at the institutional level one cannot get to that co-implication through affect theory, which points to a corporeal affective domain both before and outside of reason, meaning and intent (Leys, 2011; Massumi, 2002). Affects, unlike emotions, are non-signifying, pre-personal experiences of intensities, not signifying and intentional meanings (Leys, 2011: 441-443). For affect theorists, affects are non-semantically mediated effects, automatic responses. 
27 " [A]gape does not depend on the value of its objects... because it is unable to recognize value... [V]alue has no pertinence for agape. The gratuitousness of this form of love is qualified by its indifference to merit" (Boltanski, 2012: 111).

${ }^{28}$ Max Weber, likewise, pointed to the ways in which the impersonal brotherly ethic among the citizens of a nation-state paralleled and was in tension with the universalizing solidarities prepared by Christian salvation religion (Weber, 1958a, pp. 335-336).

29 "As Rousseau puts it in one of his 'editor's notes' to Julie, the human heart requires 'an infinite object to fill it,' and thus seeks this 'object' in God" (Maguire, 2006:126).

${ }^{30}$ This work on investment in forms sustained not only by material equipment, but by being systematically interlocked with other forms, pointed both to the productivity of conventions beyond their contribution to coordination and to institutions as bundles of conventions (Thévenot, 1984). In Thévenot's later work, production - as functionality - is essential to the regime of the plan (Thévenot, 2014: 250). If institutions, per se, do not exist, perhaps institutional logics can be empirically identified as coherent and meaningful bundles of conventions (Friedland, 2015).

${ }^{31}$ For Boltanski, there is a temporal disjunction between the two: The justice of distribution is retrospective; the justification by production is prospective, temporally located in the past and the future (Boltanski, 2012: 115).

${ }^{32}$ Thévenot's earlier theorization of investment in forms as specifying input-output relations (Thévenot, 1984) was not thematized in On Justification which focused explicitly, as Boltanski makes clear, on the distributional aspect of justice (Boltanski, 2012: 112-113).

33 Accordingly Boltanski gives generality and centrality to domination, not exploitation. In On Critique Boltanski understands "exploitation" in neo-Ricardian distributional terms: "Exploitation refers to the way that a small number of people make use of differentials...in order to extra a profit at the expense of the great majority" (Boltanski, 2011: 9).

${ }^{34}$ Gadrey and Hatchuel (2001) have criticized Boltanski and Chiapello for their neglect of the economy, particularly the rise of financialization. They replied that not only did financialization post-date their period of study, 1965-1995, but that the critique of neo-liberalism typically neglects the role of critique in generating financialization in the first place. "Ce parti pris nous a egalement conduit a minimiser de facon systematique - au profit d'un accent mis sur l'incertitude des situation - les effets systemiques et les aspects proprement economiques des situations traverses par nos acteurs, critiques et capitalists, ce qui est sans doute une autre facon de comprendre ce que J.Gadrey appelle notre 'exclusion de l'economie." (Chiapello \& Boltanski, 2001, p. 431).

${ }^{35}$ In French actif also means "asset" but Boltanksi and Esquerre explicitly write that they do not use this term strictly in an accounting sense (2014: 59).

${ }^{36}$ The co-implication of love and violence is there in Boltanski's own formulation that one must move up to a register of justice to reveal the tacit violence of material format (Boltanski, 2012: 75). The logical implication is that things must appear in some sense loving when they are just, indeed, when they are fair, affording possibilities of a given good without much human effort.

37 "It is doubtful whether institutions...can derive exclusively from a process of self-emergence set off by interactions and their repetition in the course of action. Such processes...do not seem capable of rendering the way in which institutions support the qualification of being intelligible" (Boltanski, 2011: 80).

${ }^{38}$ Social theorists can specify institutional entities because actors do so in order to provide "themselves with a representation of the reality in which they are immersed and above all of seeking to bond with one another lastingly..." (2011: 60). It is the institution that allows the analyst to suspend the notion of an "immanent agreement" in social life.

39 "The crucial element in collective intentionality is a sense of doing (wanting, believing, etc.) something together, and the individual intentionality that each person has is derived from the collective intentionality that they share" (Searle, 1995, pp. 24-25). "Intentionality is the word 
philosophers use to describe that feature of minds by which mental states are directed at or about objects and states of affairs in the world." (Searle, 2006, p. 16).

${ }^{40}$ In a related move John Levi-Martin has argued that the category of institution reflects the coming to consciousness of patterns of conduct, and specifically the persistent alignment of such conduct (Martin, 2011: 303, 305). Martin puts it this way: "[W]e can use the term institution, then, to refer not to a pattern of regularized conduct, but the intersubjectively valid representation of the patterning of that regularized conduct" (Martin, 2011, p. 303).

${ }^{41}$ Objects are critical elements in establishing a justified "test" of the relative worth of beings. Objects, however, have a delimited role to play. Speaking of "reality tests," Boltanski writes: "people were led to put their claims to the test of reality by confronting them with objects, material or symbolic, arranged in situations." (2011: 28). 